\title{
Serpentinization: Connecting Geochemistry, Ancient Metabolism and Industrial Hydrogenation
}

\author{
Martina Preiner ${ }^{1, *} \mathbb{C}$, Joana C. Xavier ${ }^{1}\left(\mathbb{C}\right.$, Filipa L. Sousa ${ }^{2}$, Verena Zimorski ${ }^{1}$, Anna Neubeck ${ }^{3}$, \\ Susan Q. Lang ${ }^{4}$, H. Chris Greenwell ${ }^{5}{ }^{\circledR}$, Karl Kleinermanns ${ }^{6}$, Harun Tüysüzz ${ }^{7}$, \\ Tom M. McCollom ${ }^{8}$, Nils G. Holm ${ }^{9}$ and William F. Martin ${ }^{1, *}$ \\ 1 Institute of Molecular Evolution, University of Düsseldorf, 40225 Düsseldorf, Germany; \\ xavier@hhu.de (J.C.X.); zimorski@hhu.de (V.Z.) \\ 2 Division of Archaea Biology and Ecogenomics, Department of Ecogenomics and Systems Biology, \\ University of Vienna, Althanstrasse 14 UZA I, 1090 Vienna, Austria; filipa.sousa@univie.ac.at \\ 3 Department of Earth Sciences, Palaeobiology, Uppsala University, Geocentrum, Villavägen 16, \\ SE-752 36 Uppsala, Sweden; anna.neubeck@geo.su.se \\ 4 School of the Earth, Ocean, and Environment, University of South Carolina, 701 Sumter St. EWS 401, \\ Columbia, SC 29208, USA; slang@geol.sc.edu \\ 5 Department of Earth Sciences, Durham University, South Road, DH1 3LE Durham, UK; \\ chris.greenwell@durham.ac.uk \\ 6 Institute for Physical Chemistry, University of Düsseldorf, 40225 Düsseldorf, Germany; \\ shangrila1@icloud.com \\ 7 Max-Planck-Institut für Kohlenforschung, Kaiser-Wilhelm-Platz 1, 45470 Mülheim an der Ruhr, Germany; \\ tueysuez@mpi-muelheim.mpg.de \\ 8 Laboratory for Atmospheric and Space Physics, University of Colorado, Boulder, CO 80309, USA; \\ tom.mccollom@lasp.colorado.edu \\ 9 Department of Geological Sciences, Stockholm University, SE-106 91 Stockholm, Sweden; \\ Nils.Holm@geo.su.se \\ * Correspondence: preiner@hhu.de (M.P.); bill@hhu.de (W.F.M.); Tel.: +49-(0)211-81-12736 (M.P.)
}

Received: 27 August 2018; Accepted: 20 September 2018; Published: 22 September 2018

\begin{abstract}
Rock-water-carbon interactions germane to serpentinization in hydrothermal vents have occurred for over 4 billion years, ever since there was liquid water on Earth. Serpentinization converts iron(II) containing minerals and water to magnetite $\left(\mathrm{Fe}_{3} \mathrm{O}_{4}\right)$ plus $\mathrm{H}_{2}$. The hydrogen can generate native metals such as awaruite $\left(\mathrm{Ni}_{3} \mathrm{Fe}\right)$, a common serpentinization product. Awaruite catalyzes the synthesis of methane from $\mathrm{H}_{2}$ and $\mathrm{CO}_{2}$ under hydrothermal conditions. Native iron and nickel catalyze the synthesis of formate, methanol, acetate, and pyruvate-intermediates of the acetyl-CoA pathway, the most ancient pathway of $\mathrm{CO}_{2}$ fixation. Carbon monoxide dehydrogenase (CODH) is central to the pathway and employs $\mathrm{Ni}^{0}$ in its catalytic mechanism. $\mathrm{CODH}$ has been conserved during 4 billion years of evolution as a relic of the natural $\mathrm{CO}_{2}$-reducing catalyst at the onset of biochemistry. The carbide-containing active site of nitrogenase-the only enzyme on Earth that reduces $\mathrm{N}_{2}$-is probably also a relic, a biological reconstruction of the naturally occurring inorganic catalyst that generated primordial organic nitrogen. Serpentinization generates $\mathrm{Fe}_{3} \mathrm{O}_{4}$ and $\mathrm{H}_{2}$, the catalyst and reductant for industrial $\mathrm{CO}_{2}$ hydrogenation and for $\mathrm{N}_{2}$ reduction via the Haber-Bosch process. In both industrial processes, an $\mathrm{Fe}_{3} \mathrm{O}_{4}$ catalyst is matured via $\mathrm{H}_{2}$-dependent reduction to generate $\mathrm{Fe}_{5} \mathrm{C}_{2}$ and $\mathrm{Fe}_{2} \mathrm{~N}$ respectively. Whether serpentinization entails similar catalyst maturation is not known. We suggest that at the onset of life, essential reactions leading to reduced carbon and reduced nitrogen occurred with catalysts that were synthesized during the serpentinization process, connecting the chemistry of life and Earth to industrial chemistry in unexpected ways.
\end{abstract}

Keywords: rock-water-carbon interactions; origin of life; carbides; iron sulfur; early metabolism 


\section{Abiotic Chemical Synthesis at Hydrothermal Vents}

Since their discovery, hydrothermal vents have been of interest in thoughts about the origin of life [1,2]. They are relevant to origins for a number of reasons. From the standpoint of thermodynamics, hydrothermal systems harbor chemical reactions that are continuously far from equilibrium, a property they share with life [3-5], and they harbor gradients: Temperature gradients, $\mathrm{pH}$ gradients, and redox gradients [2,6]. Today, those gradients are most pronounced at the vent ocean interface, where vent effluent emerges into sea water and forms hydrothermal mounds [6,7]. But life is - to our knowledge - not arising anew today. Rather life emerged once. We can say that because all life forms we know (the only ones that demand an explanation) share the same genetic code, this can only be reasonably explained by common ancestry [8]. Carbon isotopes with signatures typical for life that appear in rock 3.95-3.8 Ga of age $[9,10]$ provide the currently known date for the emergence of life.

Though views on the origin of life are traditionally marked by debate, everyone agrees that energy was important, because without energy uptake and release, no chemical reactions can take place, and if no chemical reactions take place, life forms can neither arise nor multiply. Chemical reactions require the flow of energy in order to be initiated and proceed. The main sources of energy at origins that are currently discussed in the literature are $U V$ light [11,12], lightning that generates nitric oxides as oxidants [13], kinetic energy of meteorite impacts [14,15], hydrothermally generated ion gradients [16-18], and chemical energy in the form of the $\mathrm{H}_{2}-\mathrm{CO}_{2}$ redox couple [19-25].

This paper will focus on $\mathrm{H}_{2}$-dependent $\mathrm{CO}_{2}$ reduction in hydrothermal systems and its possible significance at origins. We will discuss $\mathrm{H}_{2}$ synthesis in hydrothermal systems via serpentinization, $\mathrm{H}_{2}$-dependent organic synthesis at modern vents, and $\mathrm{H}_{2}$-dependent reduction of inorganic compounds in the crust to generate catalysts (native metals and carbides) that are used in the laboratory and in industry for $\mathrm{H}_{2}$-dependent reduction of $\mathrm{CO}_{2}$ and $\mathrm{N}_{2}$. Catalysts are important because they increase reaction rates by lowering the activation energy. They also have a drastic effect on the type of products formed because in thermodynamically controlled reactions the most stable products accumulate, whereas in kinetically controlled reactions the most rapidly formed products accumulate. The nature of the most rapidly formed products is usually governed by the chemical and physical properties of the catalyst.

We will outline clear links between vents and well-studied existing life forms. Modern anaerobic autotrophs that live from the $\mathrm{H}_{2}-\mathrm{CO}_{2}$ couple, acetogens and methanogens, have a conserved native metal $\left(\mathrm{Ni}^{0}\right)$ in their most central $\mathrm{CO}_{2}$ reducing enzyme-carbon monoxide dehydrogenase (CODH) [26,27] —and a carbide in the only enzyme that introduces $\mathrm{N}_{2}$ into biology, nitrogenase [28,29]. At the same time, $\mathrm{H}_{2}$-dependent reduction of inorganic compounds uncovers interesting links between vents and important industrial processes, because serpentinization yields not only $\mathrm{H}_{2}$, but also $\mathrm{Fe}_{3} \mathrm{O}_{4}$, which is the starting catalyst for $\mathrm{CO}_{2}$ hydrogenation to synthetic gasoline [30] and for $\mathrm{N}_{2}$ reduction to $\mathrm{NH}_{3}$ through the Haber-Bosch process [31,32].

That the chemical conditions, minerals and metallic compounds of hydrothermal vents could serve as sites of chemical synthesis of organic compounds on the early Earth is hardly a new idea [3,33,34]). Shock and Schulte [35] investigated the thermodynamics of hydrothermal systems, predicting nearly complete conversion of inorganic $\mathrm{CO}_{2}$ to organic compounds under some conditions, emphasizing that organic compounds should even be more stable than mixtures of their precursors $\mathrm{H}_{2}$ and $\mathrm{CO}_{2}$ under a variety of conditions. Amend and Shock [36] showed that the synthesis of amino acids was thermodynamically favorable under hydrothermal vent conditions. Amend and McCollom [37] explored the thermodynamics of low temperature vents similar to Lost City (low temperature, slight $\mathrm{pH}$ gradients between effluent and sea water), and found that synthesis of organic compounds in the composition and stoichiometry of biomass from inorganic precursors is thermodynamically favorable ( -1016 to -628 Joules per cell) at 50 to $100{ }^{\circ} \mathrm{C}$. Clearly, there is substantial potential for organic synthesis at today's hydrothermal vents and likely more so in vents on the early Earth. If life 
really started 3.8-3.95 billion years ago [9], we need to consider the state of the very early Earth, the setting within which the first hydrothermal systems formed.

\section{The Early Earth: Magma, then Crust, then Oceans}

The early Earth was molten following the moon-forming impact roughly 4.4 billion years ago, at the latest $[38,39]$. With temperatures on the molten Earth around $>1200^{\circ} \mathrm{C}$, carbon that had been brought to Earth by accretion was converted to $\mathrm{CO}_{2}$, which was outgassed into the atmosphere [38,40], with a portion of $\mathrm{CO}_{2}$ remaining in magma oceans [41]. Magma oceans also retained little water, which was predominantly converted to atmospheric steam. By about $4.4 \mathrm{Ga}$ the magma ocean had cooled [42] and by about $4.2 \mathrm{Ga}$ there was liquid water on Earth [38,39], some condensed from the atmosphere and some delivered later by comets. By around $4 \mathrm{Ga}$ the late heavy bombardment had ended [42,43]. By $3.95 \mathrm{Ga}$ a carbon isotopic signature compatible with that produced by the acetyl-CoA pathway had appeared [9].

As it relates to hydrothermal vents and organic synthesis, the relevant sequence of events starts from $\mathrm{CO}_{2}$ as a result of magma oceans and minor amounts of mantle $\mathrm{CO}_{2}$. In the molten state, the densest material of the early Earth-metals in the elemental state-was drawn to the planet's center where it remains to this day as the core (mainly $85 \% \mathrm{Fe}$ and $5 \% \mathrm{Ni}$ ). This process of differentiation (gravitational metal migration to the core) did not completely separate heavy material from light, because some light elements also exist in the core, such as $\mathrm{Si}$, $\mathrm{S}$, and $\mathrm{C}$, estimated at $6 \%, 2 \%$, and $0.2 \%$ respectively [44]. Lighter material consisting mainly of silicates (iron, magnesium, and aluminum silicates), possibly with residual metals, was displaced to the surface accordingly, where it formed the primordial mantle and crust. The crust started as magma and, thus, had a very low water content [38]. As the crust cooled, water eventually condensed over the Earth's surface to form oceans of liquid water $[38,40,45,46]$.

As liquid oceans formed, gravity pulled water into cracks of the steadily cooling crust. Water in the crust became heated and resurfaced, creating convective currents. The primordial ocean was about twice as deep as today's because the modern crust and mantle bind about one ocean volume of water $[40,47]$, which was originally in the ocean before rock-water interactions in the primordial crust commenced. The $\mathrm{CO}_{2}$ content of the primordial atmosphere was perhaps 100-1000 times higher [40] than today's, and very large amounts of $\mathrm{CO}_{2}$ were, thus, dissolved in the ocean. Convective water currents through the very dry iron magnesium silicate crust led to rock-water interactions, initiating a process called serpentinization, as sketched in Figure 1.

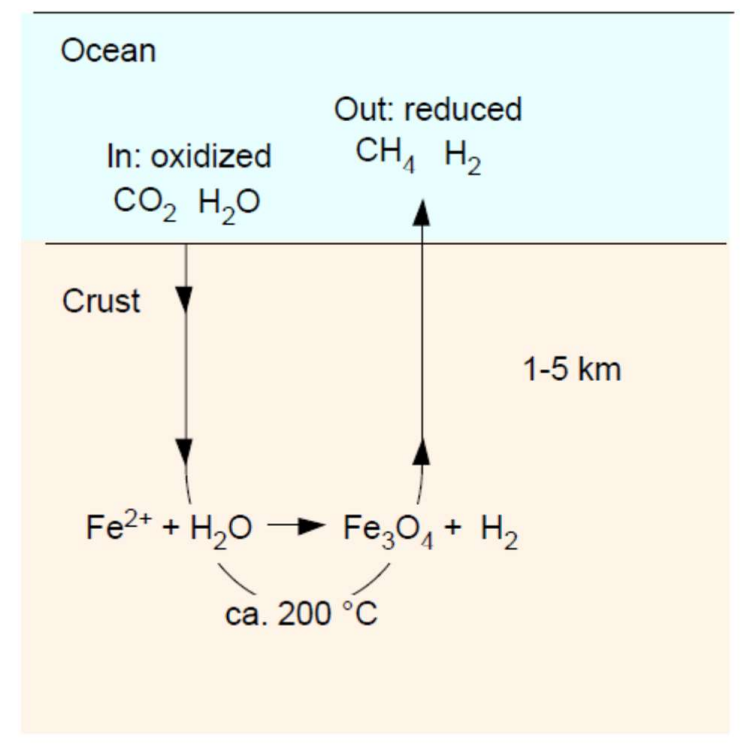

Figure 1. Schematic representation of serpentinization in a hydrothermal vent. See text and [5,48-52]. 


\section{Serpentinization: Rock-Water Interactions}

Serpentinization occurs when ultramafic rocks, enriched in the minerals olivine and orthopyroxene, react with water and are converted to rocks containing a suite of minerals dominated by serpentine. A significant by-product of the reaction is $\mathrm{H}_{2}$. In general terms, the process can be summarized by the general reaction:

$$
\text { Olivine } \pm \text { orthopyroxene }+\mathrm{H}_{2} \mathrm{O} \rightarrow \text { serpentine } \pm \text { brucite }+ \text { magnetite }+\mathrm{H}_{2} \text {. }
$$

In somewhat more precise terms, the reaction can be expressed as:

$$
\begin{gathered}
\mathrm{Mg}_{1.8} \mathrm{Fe}_{0.2} \mathrm{SiO}_{4}[\text { olivine }]+\mathrm{Mg}_{1.8} \mathrm{Fe}_{0.2} \mathrm{Si}_{2} \mathrm{O}_{6}[\text { orthopyroxene }]+\mathrm{wH}_{2} \mathrm{O} \\
0.5\left(\mathrm{Mg}, \mathrm{Fe}^{2+}, \mathrm{Fe}^{3+}\right)_{3}\left(\mathrm{Si}, \mathrm{Fe}^{3+}\right)_{2} \mathrm{O}_{5}(\mathrm{OH})_{4}[\text { serpentine }]+x\left(\mathrm{Mg}, \mathrm{Fe}^{2+}\right)(\mathrm{OH})_{2}[\text { brucite }] \\
+y \mathrm{Fe}_{3} \mathrm{O}_{4}[\text { magnetite }]+z \mathrm{H}_{2}
\end{gathered}
$$

where the stoichiometric coefficients $w, x, y$, and $z$ are variable and depend on a number of factors including temperature and the relative proportions of olivine and orthopyroxene in the reacting rock $[48,49]$. The production of $\mathrm{H}_{2}$ during serpentinization results from the oxidation of ferrous iron $\left(\mathrm{Fe}^{2+}\right)$ from the reactant minerals to ferric iron $\left(\mathrm{Fe}^{3+}\right)$ in the products through reaction with water, liberating $\mathrm{H}_{2}$. This process can be expressed as:

$$
2\left(\mathrm{Fe}^{2+} \mathrm{O}\right)+\mathrm{H}_{2} \mathrm{O} \rightarrow\left(\mathrm{Fe}^{3+}{ }_{2} \mathrm{O}_{3}\right)+\mathrm{H}_{2}
$$

where $\left(\mathrm{Fe}^{2+} \mathrm{O}\right)$ and $\left(\mathrm{Fe}^{3+}{ }_{2} \mathrm{O}_{3}\right)$ represent components of reacting rocks and product minerals, respectively. Magnetite is often the major product of $\mathrm{Fe}^{2+}$ oxidation during serpentinization. In some serpentinizing systems, sufficient amounts of $\mathrm{H}_{2}$ accumulate to reduce $\mathrm{Fe}^{2+}$ and $\mathrm{Ni}^{2+}$ (a trace component of olivine), converting them to native metal alloys such as awaruite $\left(\mathrm{Ni}_{3} \mathrm{Fe}\right)[53,54]$.

$$
\left(\mathrm{Fe}^{2+} \mathrm{O}\right)+3\left(\mathrm{Ni}^{2+} \mathrm{O}\right)+4 \mathrm{H}_{2} \rightarrow \mathrm{Ni}_{3} \mathrm{Fe} \text { [awaruite] }+4 \mathrm{H}_{2} \mathrm{O}
$$

where $\left(\mathrm{Fe}^{2+} \mathrm{O}\right)$ and $\left(\mathrm{Ni}^{2+} \mathrm{O}\right)$ again represent components of the reacting rock. The essence of serpentinization is, ultimately, that $\mathrm{Fe}^{2+}$ is oxidized by water, water is consumed by the reaction, the oxidized $\mathrm{Fe}^{2+}$ and the newly formed oxygen remain as magnetite $\left(\mathrm{Fe}_{3} \mathrm{O}_{4}\right)$, the water is reduced to $\mathrm{H}_{2}$, and the vent fluid becomes alkaline ( $\mathrm{pH}$ 9-11) [6] due to hydroxides being generated. Notably, magnetite, $\mathrm{Fe}_{3} \mathrm{O}_{4}$, and $\mathrm{H}_{2}$ are the starting materials for industrial catalysts used for $\mathrm{N}_{2}$ reduction via the Haber-Bosch process, to which we will return in a later section. Liquid gasoline synthesis from $\mathrm{H}_{2}$ and $\mathrm{CO}_{2}$, according to new findings [30] is also efficiently and specifically (up to $22 \% \mathrm{CO}_{2}$ conversion and $78 \%$ of products) catalyzed with magnetite. In industrial $\mathrm{CO}_{2}$ reduction, iron catalysts are often the choice for high-temperature processes.

However, if we consider serpentinization as a source of energy and electrons for organic synthesis at the origin of life [5,50-52] or as a source of energy and electrons for the first ecosystems on Earth $[38,55,56]$, we have to extrapolate back from modern systems. Importantly, only ultramafic (silica-poor) rocks can undergo serpentinization. The ultramafic rocks that are serpentinized in today's ocean lithosphere represent chunks of the mantle that are tectonically uplifted to shallow environments where serpentinization happens owing to lower temperatures $[57,58]$. Since the composition of the mantle does not appear to have changed significantly over time, primordial serpentinization should not have been fundamentally different from the modern process. Furthermore, a possibly thinner crust and the eruption of extrusive ultramafic volcanic rocks called komatiites because of higher mantle temperatures would have made this process more widespread on the early Earth than it currently is [35]. The primordial crust contained minor amounts of residual $\mathrm{Fe}^{0}$ and $\mathrm{Ni}^{0}$ from differentiation, and the ocean water circulating through the crust contained much more $\mathrm{CO}_{2}$ than present day. 
On the modern seafloor, fluids discharged from serpentinizing systems contain up to $16 \mathrm{mmol} \mathrm{H}_{2} / \mathrm{kg}[59,60]$. Laboratory simulations of serpentinization generate comparable and higher $\mathrm{H}_{2}$ concentrations [61-63]. Hydrothermal fluids from serpentine-hosted seafloor systems are also commonly enriched in $\mathrm{CH}_{4}$, up to several $\mathrm{mmol} / \mathrm{kg}[59,60]$. The exact temperature and pressure in natural serpentinizing systems are not known, serpentinization experiments in simulated hydrothermal systems show good results from $400{ }^{\circ} \mathrm{C}$ down to nearly ambient temperatures $[64,65]$.

\section{Serpentinization: Awaruite and Carbon}

Some serpentinization loci are naturally richer in nickel and iron minerals than others, leading to alloys containing compounds like taenite ( $\mathrm{NiFe}, 25-40 \% \mathrm{Ni}$ ), kamacite $(\mathrm{NiFe}, \mathrm{ca} .7 \% \mathrm{Ni})$, or awaruite $[65,66]$. The Ni-Fe alloys produced in serpentinizing systems are primarily awaruite, which can have a somewhat narrow range of composition from $\mathrm{Ni}_{2} \mathrm{Fe}$ to $\mathrm{Ni}_{3} \mathrm{Fe}\left(\mathrm{Ni}_{2-3} \mathrm{Fe}\right)$. Awaruite is a minor but fairly widespread component of serpentinized rocks $[53,66,67]$. Its mechanism of synthesis and/or deposition are not known in detail, but it is known to be generated by serpentinization because it occurs in hydrothermally altered serpentinite rocks [52,68]. It is thought to arise from the $\mathrm{H}_{2}$-dependent reduction of $\mathrm{Fe}^{2+}$ and $\mathrm{Ni}^{2+}$ containing minerals during the serpentinization process $[53,66]$. In a laboratory simulation of serpentinization, McCollom [68] reported the laboratory synthesis of awaruite from $\mathrm{Ni}$-containing olivine under conditions that generated ca. $60 \mathrm{mmol} / \mathrm{kg}$ $\mathrm{H}_{2}$. In the temperature range $200-400{ }^{\circ} \mathrm{C}$, high $\mathrm{H}_{2}$ activities and low $\mathrm{H}_{2} \mathrm{~S}$ activities favor awaruite formation [53]. Foustoukos et al. [54] report that awaruite can be formed at $\mathrm{H}_{2} \mathrm{~S}$ activities of ca. $1 \mathrm{mmol} / \mathrm{kg}$ and at $\mathrm{H}_{2}$ activities of $<100 \mathrm{mmol} / \mathrm{kg}$, in line with findings from laboratory awaruite synthesis [68].

Serpentinization in submarine hydrothermal systems has been around since there was water on Earth [55]. Contingent upon a heat source and cooling rates at the ridge axis, the reaction runs continuously until the host rocks are completely serpentinized, or the supply of water is exhausted. Lost City is at least 30,000 years old [69] and possibly 100,000 years old [70], indicating that these systems can be fairly long-lived. Lost City effluent contains $1-2 \mathrm{mmol} / \mathrm{kg}$ methane [71], with formate being the second most prevalent carbon species [72]. Like methane, the isotopic composition of Lost City formate indicates an abiotic origin [56,72]. Smaller amounts of ethane, propane, and butane are also observed in a serpentinizing environment and attributed to abiological synthesis [71,73-75].

During the lifespan of a serpentinizing vent, the rock reacts and its composition changes, altering the redox state and chemical composition of its surfaces, an aspect that might be relevant in terms of catalyst formation during serpentinization.

A study by Horita and Berndt [76] illustrates the principle. In laboratory experiments to better understand the presence of methane in hydrothermal effluent, they examined the reduction of $\mathrm{CO}_{2}$ with $\mathrm{H}_{2}$ to $\mathrm{CH}_{4}$ using awaruite as the catalyst. At temperatures from $200-400{ }^{\circ} \mathrm{C}$, pressure at 50 bar (5 MPa), and $\mathrm{H}_{2}$ activities around $200 \mathrm{mmol} / \mathrm{kg}$, they obtained $1-10 \mathrm{mmol} / \mathrm{kg} \mathrm{CH}$, often with $>50 \%$ conversion rates of $\mathrm{CO}_{2}$ added. The point is that awaruite (the catalyst) is not a pre-existing component of the rocks that host hydrothermal systems. Awaruite is first synthesized on site by the serpentinization process, and once formed it can then catalyze the $\mathrm{H}_{2}$-dependent reduction of $\mathrm{CO}_{2}$.

The study of Horita and Berndt [76] points to the significance of native metals in rock-water-carbon interactions more generally. Heinen and Lauwers [77] investigated the ability of $\mathrm{Fe}^{0}$ to catalyze $\mathrm{CO}_{2}$ reduction in the presence of $\mathrm{H}_{2} \mathrm{~S}$ to obtain thiols in an early evolution context. They obtained modest thiol yields (nmol), but they only analyzed volatile $\mathrm{S}$ containing compounds.

In the laboratory, good rates of $\mathrm{CO}_{2}$ conversion have been reported under hydrothermal conditions using native metals as catalysts and reductants. Guan et al. [78] showed that $\mathrm{Fe}^{0}$ in the presence of potassium, copper and aluminum will reduce $\mathrm{CO}_{2}$ to $\mathrm{CH}_{4}, \mathrm{C}_{3} \mathrm{H}_{8}, \mathrm{CH}_{3} \mathrm{OH}$, and $\mathrm{C}_{2} \mathrm{H}_{5} \mathrm{OH}$ in the $10-70 \mu \mathrm{M}$ range in $20 \mathrm{~h}$ at room temperature. He et al. [79] reported a reduction of $\mathrm{CO}_{2}$ to formate and acetate in the $1-10 \mathrm{mM}$ range using nanoparticular $\mathrm{Fe}^{0}$ at $80-200{ }^{\circ} \mathrm{C}$ for 5 to $200 \mathrm{~h}$. Varma et al. [80] used $\mathrm{Fe}, \mathrm{Ni}, \mathrm{Mo}, \mathrm{Co}$, and $\mathrm{W}$ at temperatures between $30-100{ }^{\circ} \mathrm{C}$, all with some success, but the 
best yields (10-200 $\mu \mathrm{M}$ concentrations of reduced carbon compounds) were observed with $\mathrm{Fe}^{0}$ in presence of potassium salts. Importantly, the reduced carbon products observed by Guan et al. [78], He et al. [79], and Varma et al. [78] are compounds that also occur as intermediates and end products in the metabolism of organisms, such as acetogenic bacteria and methanogenic archaea [81,82], that live on $\mathrm{H}_{2}$ and $\mathrm{CO}_{2}$ as the substrates for their carbon and energy metabolism: Formate, methyl moieties, and acetate. Varma et al. [80] even reported the synthesis of pyruvate at temperatures of $100{ }^{\circ} \mathrm{C}$ and below.

In terms of microbial physiology, Varma et al.'s [80] findings are very significant because the reduction of $\mathrm{CO}_{2}$ to pyruvate-presumably via formate, methyl groups, and acetyl groups-exactly mirrors the reaction sequence in the acetyl-CoA pathway, the pathway of carbon and energy metabolism in organisms that live from the reduction of $\mathrm{CO}_{2}$ with $\mathrm{H}_{2}$ [83,84]. Stated another way, when $\mathrm{CO}_{2}$ and native metals react in water overnight under strictly anaerobic conditions, the core reaction sequence of the most ancient pathway of microbial carbon and energy metabolism, the acetyl-CoA pathway $[24,83,85,86]$, which operates in the most ancient microbial lineages $[87,88]$ unfolds in a series of spontaneous non-enzymatic reactions in the presence of water. The pressures employed by Varma et al. [80] do not preclude, however, the existence of a gas phase. At depths of several $\mathrm{km}$, very high gas activities can be attained, but the pressure (hundreds of bars) would seem to be too high for a gas phase. However, Früh-Green et al. [89] reported gas bubbles arising during drilling around vents at the Atlantis Massif at a depth of 1,140 m.

Noteworthy in the study of Varma et al. [80] is that the products of $\mathrm{CO}_{2}$ reduction appear to be synthesized and bound on the surface of the metals, such that they had to be cleaved by alkaline hydrolysis to be assayed. It is not clear whether the products were bound to the Fe particles via C-Fe bonds or C-O-Fe bonds, because there was no surface analysis so far, but alkaline hydrolysis was required to obtain the soluble products. In the studies of He et al. [79] and Guan et al. [78] some fraction of the reduced carbon products was probably discarded, bound to metal surfaces. Reaction mechanisms for $\mathrm{CO}_{2}$ reduction have been proposed by He et al. [79] and Varma et al. [80] but the exact role of $\mathrm{H}_{2}$ and $\mathrm{Fe}^{0}$ in $\mathrm{CO}_{2}$ reduction is not yet clear. Heinen and Lauwers [77] showed that under anaerobic conditions, $\mathrm{Fe}^{0}$ and $\mathrm{H}_{2} \mathrm{O}$ readily generate $\mathrm{H}_{2}$ which, in the presence of the metal, readily reduces $\mathrm{CO}_{2}$. Guan et al. [78] reported that roughly $0.3 \mathrm{~mol} \mathrm{H}_{2}$ was generated per mol Fe${ }^{0}$.

Awaruite was also reported to catalyze the reduction of $\mathrm{N}_{2}$ with $\mathrm{H}_{2}$, but at very low rates just above background [90]. Under simulated deep crust conditions comparable to the Haber-Bosch process $\left(>300{ }^{\circ} \mathrm{C}\right.$ ), but without exogenous $\mathrm{H}_{2}$, the reduction of $\mathrm{N}_{2}$ to $\mathrm{NH}_{3}$ on native iron was reported [91], as were low conversion rates $(\sim 0.1 \%)$ of $\mathrm{N}_{2}$ to $\mathrm{NH}_{3}$ with $\mathrm{H}_{2} \mathrm{~S}$ in the presence of $\mathrm{FeS}$ at ambient pressure and $90{ }^{\circ} \mathrm{C}$ [92]. On the scales of submarine crust volume and geological time, a constant supply of small amounts of reduced nitrogen, or activated nitrogen species on metal catalyst surfaces, could easily be sufficient to underpin prebiotic synthesis of nitrogenous carbon compounds [93].

\section{Serpentinization: Methane}

Distinctive $\mathrm{C}$ and $\mathrm{H}$ isotope signatures and other evidence indicate that the methane discharged from many serpentinizing systems has an abiotic origin [71,74,75]. Presumably, this methane is produced as the $\mathrm{H}_{2}$ produced by serpentinization reacts with $\mathrm{CO}_{2}$ :

$$
\mathrm{CO}_{2}+4 \mathrm{H}_{2} \rightarrow \mathrm{CH}_{4}+2 \mathrm{H}_{2} \mathrm{O}
$$

Although exactly where in the system and how it is produced remains a matter of ongoing debate $[74,75,94,95]$. In the absence of catalysis, reduction of dissolved $\mathrm{CO}_{2}$ is extremely slow even at temperatures up to $350{ }^{\circ} \mathrm{C}[33,68,96]$. However, when suitable catalysts such as awaruite are available, or when $\mathrm{CO}_{2}$ and $\mathrm{H}_{2}$ are present in a gas phase, the reaction can proceed much more readily $[22,33,75,76]$. It is this kinetic inhibition that allows $\mathrm{CO}_{2}$ and $\mathrm{H}_{2}$ to remain in disequilibrium and be exploited as an energy source by methanogenic organisms in hydrothermal environments. 
Reduction of dissolved $\mathrm{CO}_{2}$ to formate proceeds readily under simulated hydrothermal conditions and, as mentioned above, formate is observed in modern hydrothermal vent effluent, although typically at lower concentrations than methane [72,74,97].

Today, the formation of abiotic methane is important as a substrate for methanotrophic organisms in an oxidizing environment. In an origin of life context, methane itself is probably not of central interest, because of its very strong $\mathrm{C}-\mathrm{H}$ bond. At great depths in the oceanic crust and in the upper mantle dominated by the fayalite-magnetite-quartz (FMQ) redox buffer, $\mathrm{CO}_{2}$ is the dominant carbon species at stable equilibrium [20]. At temperatures above about $350{ }^{\circ} \mathrm{C}$, equilibrium between $\mathrm{CO}_{2}$ and $\mathrm{CH}_{4}$ favors $\mathrm{CO}_{2}$ even at elevated $\mathrm{H}_{2}$ concentrations $[5,20]$. However, with decreasing temperature, the equilibrium shifts to favor $\mathrm{CH}_{4}$, so that at temperatures below $\sim 350{ }^{\circ} \mathrm{C}$ reaction of $\mathrm{CO}_{2}$ with $\mathrm{H}_{2}$ to form $\mathrm{CH}_{4}$ is thermodynamically favored. If the activation energy is too high and kinetic hindrances arise that prevent equilibrium conditions from being established, the organic chemistry will be locked up in different organic metastable compounds such as carboxylic acids. If nitrogen is present, even amino acids and nitrogen bases may be formed. Therefore, it is the interrupted transition from $\mathrm{CO}_{2}$ to $\mathrm{CH}_{4}$ that has the potential to create prebiotic constituents of life processes in the ocean floor and not $\mathrm{CH}_{4}$ itself. Organic chemists have often rejected igneous environments as a likely site for the origin of life because $\mathrm{CO}_{2}$ is a common component of fluids and gases (because of kinetic hindrances). Oparin [98], for instance, claims that 'carbon dioxide is not the beginning but the end of life'-a statement that is, of course, only true in an oxidizing environment.

\section{Serpentinization: Magnetite $\left(\mathrm{Fe}_{3} \mathrm{O}_{4}\right)$}

Magnetite is a common (although not ubiquitous) product of serpentinization. It is of interest in the context of $\mathrm{CO}_{2}$ reduction because it is the starting point to reach industrial catalysts for $\mathrm{CO}_{2}$ hydrogenation and for $\mathrm{N}_{2}$ reduction to ammonia via the Haber-Bosch process. Wei et al. [30] reported the $\mathrm{H}_{2}$-dependent reduction of $\mathrm{CO}_{2}$ to hydrocarbons $\left(\mathrm{C}_{2}-\mathrm{C}_{11}\right)$, methane, and aromatics, with up to $22 \% \mathrm{CO}_{2}$ conversion using $\mathrm{Fe}_{3} \mathrm{O}_{4}$ as the catalyst. During the reaction process, at about $320{ }^{\circ} \mathrm{C}$ and 30 bar (3 MPa), with $\mathrm{H}_{2} / \mathrm{CO}_{2}$ ratios of $1: 1$ to $6: 1, \mathrm{Fe}_{3} \mathrm{O}_{4}$ is converted by $\mathrm{H}_{2}$ in situ to iron carbide, $\mathrm{Fe}_{5} \mathrm{C}_{2}$, as analysis of the spent catalyst reveals. $\mathrm{Fe}_{5} \mathrm{C}_{2}$ is, in turn, thought to be the decisive catalyst for Fischer-Tropsch (FT) synthesis of longer hydrocarbons from $\mathrm{CO}$, which is generated on $\mathrm{Fe}_{3} \mathrm{O}_{4}$ sites via a reverse water gas shift (WGS) reaction $[30,99,100]$. Note the involvement of WGS means that $\mathrm{H}_{2} \mathrm{O}$ is present during the reaction. FT and WGS reactions have long been discussed in the context of hydrothermal organic synthesis [101,102]. That magnetite itself is not an effective catalyst, as experimental studies reveal [68,103], is not the main point here. The point, as we see it, is that the effective catalyst, an iron carbide, is synthesized from $\mathrm{CO}_{2}$ and $\mathrm{Fe}_{3} \mathrm{O}_{4}$ in the presence of $\mathrm{H}_{2}$ during the reaction that mirrors conditions and chemical components found in serpentinizing hydrothermal vents, as outlined in Figure 2.

The participation of carbides in $\mathrm{CO}_{2}$ hydrogenation is well known from processes developed for industrial application. Metal-carbide interfaces catalyze $\mathrm{CO}_{2}$ conversion into $\mathrm{CO}$ [104] or methanol [105]. The literature on Fischer-Tropsch synthesis [106,107] shows that carbides are a product of reactions with iron catalysts. This happens especially with $\mathrm{CO}$, because it decomposes to $\mathrm{CO}_{2}$ and chemisorbed carbon. The latter reacts further to produce iron carbides. As one can commonly observe magnetite, $\mathrm{Fe}_{3} \mathrm{O}_{4}$, in both fresh and spent iron catalysts, this compound is thought to be an active part of such reactions. Small amounts of native iron also seem to help the catalysis from $\mathrm{CO}$ to carbide [108]. Carbides have not been widely considered in an early evolution context, although they are also found in natural systems: Iron carbides are formed in the lower parts of the Earth's crust (called ophiolite), but are uplifted over time-some of them even containing nickel [109-111]. In all of biology, there is only one carbide carbon known. Discovered in 2011 [28,29], it resides at one of the most crucial reactions for fueling ecosystems and in one of the most ancient enzymes known, nitrogenase. 


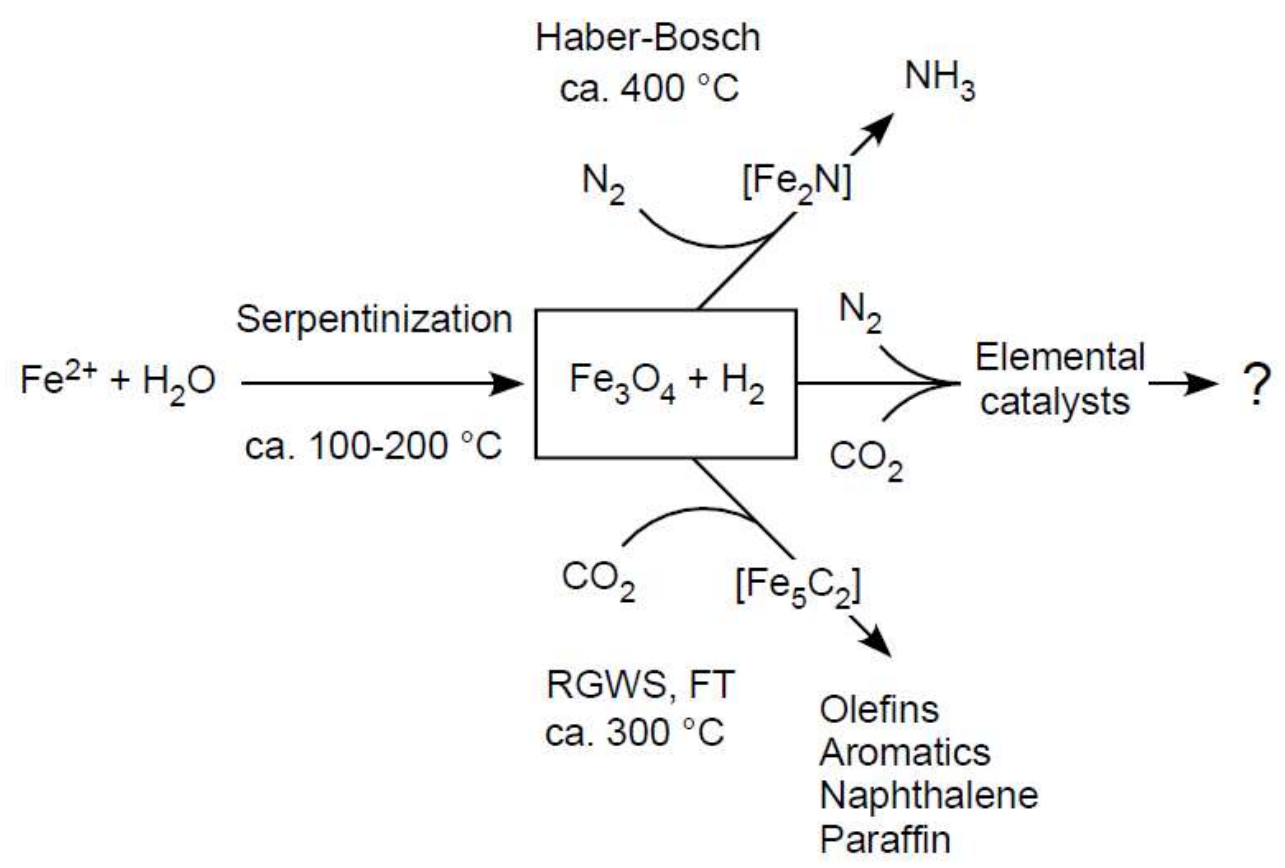

Figure 2. Possible connections between industrial processes and chemical evolution. See text. RWGS, reverse gas water shift reaction. FT, Fischer-Tropsch. The Haber-Bosch process starts with magnetite and generates nitrides [31,32]. The synthesis of gasoline from $\mathrm{CO}_{2}$ starts with magnetite and generates iron carbide, both catalysts appear to fulfill important but distinct roles [28]. Reaction parameters aimed at simultaneous reduction of $\mathrm{N}_{2}$ and $\mathrm{CO}_{2}$ are not well explored.

Magnetite itself, without carbides and without exogenous $\mathrm{H}_{2}$, can reduce $\mathrm{CO}_{2}$ in $\mathrm{H}_{2} \mathrm{O}$ to acetate with roughly $3 \%$ conversion at $250{ }^{\circ} \mathrm{C}$ [112]. The greater high-temperature catalytic ability of reduced magnetite-containing carbides [106] or nitrides [32] and the lower-temperature (100-200 $\left.{ }^{\circ} \mathrm{C}\right)$ catalytic ability of native metals [80] and awaruite [76] raise a question that needs to be spelled out clearly: Do serpentinizing hydrothermal systems improve their organic synthetic capacity during their lifespan by synthesizing better (more reduced) inorganic catalysts of organic reactions? That is, does serpentinization generate carbides and nitrides from magnetite and $\mathrm{H}_{2}$ in a similar manner to what chemical industry does? And if so, what kinds of products might one expect under conditions where both $\mathrm{CO}_{2}$ and $\mathrm{N}_{2}$ could be reduced simultaneously?

In a typical heterogeneously driven gas phase catalytic reaction, the first step of a catalytic reaction is adsorption of reactants on the surface of catalysts, followed by dissociation of reactants, product formation, and, finally, desorption of products from the surface of the catalyst. Heterogeneous catalysts naturally contain different types of catalytically active surface sites depending on their composition, crystallinity, particle size, and facet, and also impurities. If the catalyst contains several components (as the starting materials for the serpentinization process do) the surface composition might be different from a bulk structure. Moreover, the surface structure and composition of the catalyst can change dramatically during the catalytic reaction as it is the case for $\mathrm{CO}_{2}$ reduction over magnetite [30] and $\mathrm{N}_{2}$ hydrogenation to $\mathrm{NH}_{3}$ in the Haber-Bosch process [32].

This is potentially an interesting avenue of thought. The sequence of events underlying awaruite synthesis can, generally, be understood as large amounts of reduced iron and water giving rise to lesser amounts of $\mathrm{H}_{2}$, which then reduces divalent $\mathrm{Ni}$ and $\mathrm{Fe}$ in minerals to generate reduced magnetite and elemental metals $\mathrm{Ni}^{0}$ and $\mathrm{Fe}^{0}\left(\mathrm{Ni}_{3} \mathrm{Fe}\right)$ which appear to have catalytic properties when it comes to $\mathrm{H}_{2}$-dependent $\mathrm{CO}_{2}$ reduction $[76,80]$. If so, the geochemical process is synthesizing catalysts for organic synthesis-constantly. As outlined above, processes of catalyst synthesis from $\mathrm{Fe}_{3} \mathrm{O}_{4}$ and $\mathrm{H}_{2}$ are demonstrably occurring in industrial applications for reduction of $\mathrm{CO}_{2}$ and $\mathrm{N}_{2}$. 


\section{Conserved Relicts in Metabolism: $\mathrm{The}^{\mathrm{Ni}}{ }^{0}$ in $\mathrm{CODH}$}

The reaction mechanism of an ancient enzyme called carbon monoxide dehydrogenase (CODH) entails the generation of zero valent $\mathrm{Ni}\left(\mathrm{Ni}^{0}\right)$ as an intermediate in biological CO synthesis as shown in Figure 3a. CODH is involved in a pathway that is thought to be just as ancient (probably even more so) than the enzyme itself: The acetyl-CoA pathway. It is the only exergonic pathway of autotrophic carbon metabolism known $[83,85,113]$. Its exergonic nature allows acetogens and methanogens to generate transmembrane ion gradients in a process involving flavin-based electron bifurcation [114] during the process of $\mathrm{CO}_{2}$ fixation $[81,115]$ and thereby conserve energy in the form of ATP via electron transfer phosphorylation (chemiosmosis).

Flavin-based electron bifurcation is a newly discovered mechanism of soluble (as opposed to membrane-associated) energy conservation [114,116,117]. Its principle is significant and we will encounter it again in a later section so it should be briefly explained here. The midpoint potential, $E_{0}^{\prime}$, of $\mathrm{H}_{2}(-414 \mathrm{mV})$ is not sufficiently negative to generate the low-potential reduced ferredoxin $\left(E_{0}^{\prime}=\right.$ ca. $\left.-500 \mathrm{mV}\right)$ that acetogens and methanogens require and use to reduce $\mathrm{CO}_{2}$ under physiological conditions. How, then, do acetogens and methanogens send electrons from $\mathrm{H}_{2}$ energetically uphill by roughly $-100 \mathrm{mV}$ ? The electron pair from $\mathrm{H}_{2}$ is transferred to a flavoprotein, the flavin of which splits the pair: One electron goes energetically uphill to ferredoxin while the other goes energetically downhill to a more positive electron acceptor such as $\mathrm{NAD}^{+}$ $\left(E_{0}{ }^{\prime}=\right.$ ca. $\left.-320 \mathrm{mV}\right)$ [115] or a heterodisulfide $\left(E_{0}{ }^{\prime}=\right.$ ca. $\left.-140 \mathrm{mV}\right)$ [118] or similar [114]. The reduction of the downhill (more positive) acceptor energetically finances the reduction of the uphill acceptor so that ferredoxin is reduced and $\mathrm{CO}_{2}$ in the acetyl-CoA pathway can be fixed.

Although five of the six known pathways of autotrophic carbon metabolism also generate acetyl-CoA as the net end product of $\mathrm{CO}_{2}$ fixation starting with electrons from $\mathrm{H}_{2}$ [83] (the Calvin cycle generates glyceraldehyde 3-phosphate), only the acetyl-CoA pathway generates ATP from $\mathrm{CO}_{2}$ fixation. The other five require ATP input to fix $\mathrm{CO}_{2}$ [84]. That ATP input comes from an independent energy metabolism, typically aerobic or anaerobic respiration (sulfate reduction for example), that is independent of $\mathrm{CO}_{2}$ reduction. The reverse TCA cycle only requires the input of one ATP per $\mathrm{CO}_{2}[119,120]$, but it still requires ATP input. The acetyl-CoA pathway permits ATP synthesis from $\mathrm{H}_{2}$-dependent $\mathrm{CO}_{2}$ reduction. Why? It involves $\mathrm{CO}$ as an intermediate, a carbonyl moiety that becomes a carboxylate only after going through a sequence of metal carbonyl (CO-Ni), thioester ( $\mathrm{CO}-\mathrm{S})$ and acyl phosphate $\left(\mathrm{CO}-\mathrm{OPO}_{3}{ }^{2-}\right)$ bonds, the latter of which phosphorylates ADP to generate the carboxylate. In all other pathways of $\mathrm{CO}_{2}$ fixation, $\mathrm{CO}_{2}$ is fixed as a carboxylate that subsequently has to be reduced, ultimately at the expense of ATP hydrolysis [83,84]. It is the zero valent $\mathrm{Ni}$ of $\mathrm{CODH}$ that generates $\mathrm{CO}$ for the acetyl-CoA pathway; that is the chemistry that makes the pathway exergonic $[27,121,122]$.

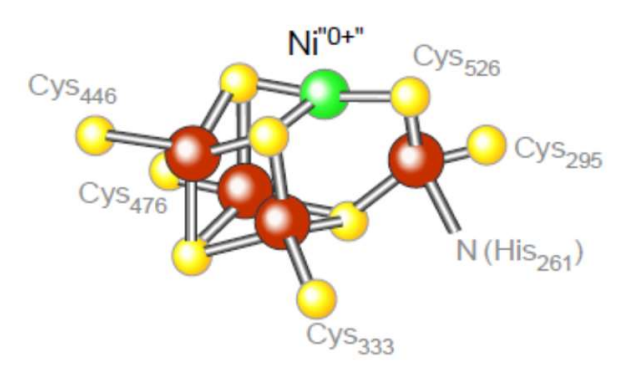

(a)

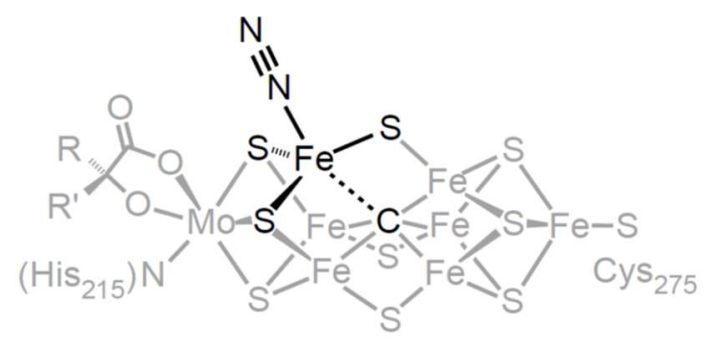

(b)

Figure 3. Relicts in metabolism. (a) The active site of $\mathrm{CODH}$ that interconverts $\mathrm{CO}_{2}$ and $\mathrm{CO}$, redrawn from supplemental figure S5 in Ragsdale [26] underscoring the reduced $\mathrm{Ni}$ atom that binds $\mathrm{CO}_{2}$ in the proposed mechanism for the CO-generating reaction. (b) The carbide carbon in the active site of nitrogenase [28,29] and its proposed role in the catalytic mechanism [123]. 


\section{Conserved Relicts in Metabolism: The Carbide in Nitrogenase}

In terms of dry weight, life is $50 \%$ carbon and $10 \%$ nitrogen. Though $\mathrm{CO}_{2}$ can enter metabolism via six known carbon fixation pathways [83], there is only one known entry point for $\mathrm{N}_{2}$ : Nitrogenase. It has long been known for its complex 7Fe-9S cluster harboring a light atom at its center and for existing in three related forms that differ with respect to the metal cofactor that is peripherally associated with the active site: Mo, V, or Fe [123-125]. It requires 16 ATP and 8 electrons per conversion of $\mathrm{N}_{2}$ into $2 \mathrm{NH}_{4}{ }^{+}$and it produces $\mathrm{H}_{2}$ as an unavoidable reaction by-product. The ATP is consumed by "archerases" in nitrogenase which hydrolyze ATP to induce conformational changes that alter the midpoint potential of $4 \mathrm{Fe} 4 \mathrm{~S}$ clusters to more negative values for $\mathrm{N}_{2}$ reduction [126].

In 2011, the light atom at the nitrogenase active site was identified as a carbon atom in the elemental state that is coordinated by four iron atoms, forming an essential $\mathrm{Fe}_{4} \mathrm{C}$ carbide at the catalytic heart of the enzyme $[28,29]$ (Figure 3b). The carbide is generated during nitrogenase maturation from a methyl group donated to an active site Fe by S-adenosyl methionine (SAM) [127]. Synthetic analogs of the active site of nitrogenase even catalyze the synthesis of hydrocarbons from CO [128].

Nitrogenase is a very ancient enzyme that traces to the last universal common ancestor (LUCA) in ancestral genome reconstructions [87]. It has never been replaced during 4 billion years of evolution, nor has an alternative enzymatic mechanism been invented among microbes that would serve the same purpose of making $\mathrm{N}$ from $\mathrm{N}_{2}$ available for biosynthesis (amino acids, cofactors, nucleotides) and growth [129]. The incorporation of nitrogen into metabolism requires an iron carbide, as models for the nitrogenase catalytic mechanism suggest [130]. There is apparently no other way for biological systems to reduce $\mathrm{N}_{2}$ with the tools of enzymes and cofactors. That suggests to us that the carbide-containing active site of nitrogenase is a biological reconstruction of the naturally occurring inorganic catalyst that gave rise to organic $\mathrm{N}$ at the onset of biochemistry.

This inference parallels the situation with a native metal $\left(\mathrm{Ni}^{0}\right)$ and $\mathrm{CO}$ synthesis in the exergonic acetyl-CoA pathway: There is apparently no mechanistic alternative to exergonic $\mathrm{CO}_{2}$ reduction with $\mathrm{H}_{2}$ that can be readily realized during 4 billion years of evolution. We suggest that elemental carbon (carbide) in nitrogenase and $\mathrm{Ni}^{0}$ in $\mathrm{CODH}$ represent relicts from the chemical environment that supported organic synthesis at life's origin.

\section{Weighing in on Caveats}

One of the strengths of hydrothermal vent theories is that over the years since their first formulations, the gaps between spontaneous chemistry at vents and the chemistry of life have narrowed, not widened. Methane made abiogenically in substantial amounts at vents $[22,52,71,72]$ stems from the same overall exergonic chemical reaction at the heart of methanogenesis in archaea, namely Equation (5). A similar case can be made for the acetogenic reaction [81,131].

$$
4 \mathrm{H}_{2}+2 \mathrm{CO}_{2} \rightarrow \mathrm{CH}_{3} \mathrm{COOH}+2 \mathrm{H}_{2} \mathrm{O}
$$

Methanogens and acetogens are identified as the most ancient archaea and bacteria respectively, in reciprocally rooted trees for genes that trace to the last universal common ancestor (LUCA) $[87,88]$. Furthermore, $\mathrm{H}_{2}$-dependent methanogens appear as the most ancient archaea in some phylogenies [132] and clostridia (acetogens) appear as the most ancient bacteria, too [133], although lineage phylogenies among prokaryotes are always in flux and inferences from them are generally problematic because lateral gene transfer decouples physiology from phylogeny [134]. More direct observations are that methanogens abundantly inhabit vents $[23,56]$ and the deep, subsurface oceanic crust $[135,136]$ today.

But what about acetate or chemically reactive methyl groups like methanol or methyl sulfide? For example, the absence of more than nanomolar amounts of methyl sulfide was taken as evidence against the hydrothermal origins theory [137], but methanethiol is avidly assimilated by methanogens and acetogens in the acetyl-CoA pathway [83]. Similar reasoning applies to acetate, which is 
very scarce in hydrothermal effluents sampled so far [72], even though it readily accumulates in experiments intended to simulate vent conditions [80]. Acetate is the carbon and energy source for aceticlastic methanogens [81] belonging to the Methanosarcinales, which are abundant at hydrothermal vents $[138,139]$, because the substrates they require for growth abound. The deep biosphere contains very large amounts of biomass $[140,141]$ consisting of microorganisms that are generally starved for reducible carbon substrate, Heberling et al. [142] estimate $200 \times 10^{9}$ tons of biomass in the marine igneous crust (that is, excluding sediment). That abiotic acetate or methylsulfide is scarce in vent effluents reported so far [56,137] might not directly reflect synthesis processes at depth, but microbial scavenging instead. Methane accumulates within vents because strong oxidants, which are typically lacking within vents, are required for methane oxidation [143].

Another criticism concerns synthesis. Miller and Bada [144] argued that FT type reactions readily catalyzed by native metals cannot generate organic compounds in hydrothermal systems because of catalyst inhibition by $\mathrm{H}_{2} \mathrm{O}$ and $\mathrm{H}_{2} \mathrm{~S}$. Holm et al. [52] explain, however, that off-axis hydrothermal systems of the Lost City type have low concentrations of $\mathrm{H}_{2} \mathrm{~S}$ [145]. Additionally, awaruite can be formed at higher $\mathrm{H}_{2} \mathrm{~S}$ activities (ca. $1 \mathrm{mmol} / \mathrm{kg}$ ) than previously thought [54], and metals other than $\mathrm{Fe}$, including $\mathrm{Ni}$, are not inhibited by $\mathrm{H}_{2} \mathrm{~S}$.

Water activities are another issue typically raised by critics of hydrothermal vent theories [146]. Water hydrolyzes RNA and interferes with many reactions that generate specific prebiotic-type syntheses of particular organic molecules. This has spawned arguments that life must have arisen on land in dry or even desert-like conditions [147] or that essential reaction sequences giving rise to RNA monomers took place in the absence of water because that is how they work best in the laboratory with energy from $U V$ light [12]. Nobody has yet proposed that RNA replication took place without water. Life is $80 \%$ water by weight, about $60 \%$ protein and $25 \%$ RNA by dry weight [148], with protein synthesis consuming about $75 \%$ of a cell's energy budget [149]; life counters hydrolysis problems by synthesizing polymers faster than they are hydrolyzed, at the expense of chemical energy.

An underappreciated aspect concerning water activity is that serpentinization takes place in rock that is initially very dry and that roughly 12 to 37 mol water is consumed per mol $\mathrm{H}_{2}$ produced (reactions 1-4). Placed in the context of methane or acetate synthesis (reactions 5-6), roughly $100 \mathrm{~mol}$ of $\mathrm{H}_{2} \mathrm{O}$ is consumed per $\mathrm{CO}_{2}$ or carbonate that is reduced to the level of a methyl group. Furthermore, a great deal of additional water is simply converted into hydroxylated minerals during serpentinization. At the same time that water is being consumed, reactive gasses $\left(\mathrm{H}_{2}, \mathrm{CO}\right)$ are being generated. Gas reactions on solid phase catalysts in serpentinization studies should not be neglected, nor should the circumstances that hydrophobic organics synthesized at hydrothermal vents will undergo phase separation and generate molecular environments of low water activity, which is the main function that enzymes provide in catalysis: Exclusion of water from the active site [150]. The crust hosting hydrothermal systems is necessarily replete with localities of low water activity and water disappears where reducing power for carbon reduction is generated.

\section{Do Genomes Help?}

Recent work has examined the origins problem from a novel top-down perspective. Standard approaches analyzed genomes to see which genes are universal to all cells, recovering about 30 genes involved in information processing [88]. Weiss et al. [87] constructed all trees for all proteins from 2000 genomes and identified proteins that are not universal to all cells but that are ancient by phylogenetic criteria. They looked for genes that trace to the LUCA because they are present in bacteria and archaea, but present by virtue of vertical inheritance from LUCA as opposed to late lateral gene transfer $[87,88]$. Based upon the kinds of genes that trace to LUCA, the results indicated that LUCA lived from dissolved gasses: $\mathrm{H}_{2}, \mathrm{CO}_{2}, \mathrm{CO}, \mathrm{N}_{2}$, and $\mathrm{H}_{2} \mathrm{~S}$. The results indicated that for carbon assimilation, LUCA used the simplest and most ancient of the six known pathways of $\mathrm{CO}_{2}$ fixation, the acetyl-CoA pathway germane to methanogenesis and acetogenesis, but it lacked the methyl synthesis branch suggesting that it relied on a geochemical supply of methyl groups. LUCA had nitrogenase, it had no traces of light utilization, 
its environment was hot, contained $\mathrm{H}_{2}, \mathrm{CO}_{2}, \mathrm{CO}, \mathrm{N}_{2}, \mathrm{H}_{2} \mathrm{~S}$, and metals-an environment that looks very much like a hydrothermal vent. Genomes trace LUCA to a site of rock-water-carbon interactions.

LUCA was able to harness ion gradients via the rotor-stator ATPase, but proteins of the ion gradient generation (pumping) were missing [87], which would have been possible, if LUCA lived at the vent of a serpentinizing system. There, geochemically generated ion gradients (alkaline inside versus the more neutral ocean) could be harnessed before the machinery was invented that allows cells to pump with the help of an ion gradient generated by a chemistry that is specified by genes $[24,131]$. In short, LUCA was half-alive, dependent upon geochemical organic synthesis and the chemical disequilibrium of its environment to harness carbon and energy. That might sound radical, but no theory for origins can operate without some kind of sustained chemical synthesis from the environment. A strong argument for origins at vents is the congruence between the basic $\mathrm{CO}_{2}$ reduction reactions of serpentinization and the chemistry of acetogen and methanogen metabolism $[24,86]$. Metabolic pathway reconstructions of phosphate independent reactions uncovered the essential role of ferredoxin-dependent redox reaction and thioesters in ancient anabolic biochemistry [151,152]. LUCA's metabolism and genetic code were heavily dependent upon methyl groups [87].

The kind of LUCA that emerges from genomic reconstruction would have starved (low $\mathrm{H}_{2}$ and $\mathrm{CO}_{2}$ activities) and perished (UV light) at the surface-what it needed to survive was provided by rock-water interactions in the crust: Reactive gasses. Perhaps the crust was the first environment on Earth to have been inhabited [4,55]. Biologists and chemists have long held that inorganic catalysts/electron donors like FeS centers preceded organic catalysts/electron donors like NADH in evolution $[153,154]$. Similarly conserved base modifications (methylations, sulfur additions) in tRNA, in particular in the anticodon loop that allows the modern genetic code to operate, reflect the chemical environment within which the genetic code arose $[87,88]$.

LUCA also harbored hydrogenases [87]. In Figure 3, the active sites of CODH and nitrogenase underscore the role of $\mathrm{Ni}^{0}$ and a carbide in the entry of carbon (from $\mathrm{CO}_{2}$ ) and nitrogen (from $\mathrm{N}_{2}$ ) into the biosphere. These active sites represent bottlenecks in the origins and early evolution of metabolism. For the reduction of carbon and nitrogen, electrons stemming from $\mathrm{H}_{2}$ as the proximal carrier were required. But in metabolism, $\mathrm{H}_{2}$ never interacts directly with $\mathrm{C}$ or $\mathrm{N}$, rather it enters metabolism via metal atoms in hydrogenases. Electrons from $\mathrm{H}_{2}$ always enter metabolism via metals in the active site of hydrogenase or hydrogenase domains. There are three different kinds of hydrogenases known, they are phylogenetically unrelated and have very different active sites: The [NiFe] hydrogenase, the [FeFe] hydrogenase, and the [Fe] hydrogenase, the latter lacking FeS clusters [155]. Common to all three active sites, however, is that $\mathrm{H}_{2}$ relinquishes its electrons via interaction with an Fe atom that is coordinated by one or more $\mathrm{CO}$ molecules [156]: Iron(II) carbonyls participate in $\mathrm{H}_{2}$ activation in three independently arisen hydrogenase active sites. In contrast to $\mathrm{CODH}$ and nitrogenase, hydrogenases have appeared three times independently in evolution, but the iron carbonyl catalyst is conserved, indicating that the catalyst is older than the proteins that harbor it.

\section{What Next?}

What has been missing from hydrothermal vent-based research on origins is a decisive experiment where a wide variety of amino acids and bases arise under genuinely realistic conditions, although an early attempt was made by Hennet et al. [34]. FeS generally does not efficiently convert $\mathrm{CO}_{2}$ into reduced carbon, either in the laboratory or in metabolism. Native metals do [80], and they furthermore generate the biologically relevant carbon species that occur at the core of metabolism: Formate, acetate, pyruvate, and methyl groups. The reason that $\mathrm{FeS}$ does not work well, but $\mathrm{Fe}^{0}$ does, stated most simply, is that $\mathrm{CO}_{2}$ reduction in biology (and perhaps more generally) is always a two-electron reaction, whereas FeS only undergoes one-electron reactions. Wächtershäuser has stressed the role of FeS in primordial biochemistry [157] and reported extensive experiments using $\mathrm{FeS}$ as a catalyst in reactions involving $\mathrm{CO}$ as a reductant, in which amino acids were observed [158]. Bases (heterocycles) have not been observed so far in FeS catalyzed reactions, nor has $\mathrm{CO}_{2}$ reduction 
using FeS catalysts ever been convincingly demonstrated in terms of reaction rates or product yields so far. $\mathrm{CO}_{2}$ reduction using $\mathrm{H}_{2}$ and $\mathrm{Ni}_{3} \mathrm{Fe}$ catalysis at higher temperatures $\left(200-400{ }^{\circ} \mathrm{C}\right.$ ) produce good yields of methane [76], but methane is rather an end product of metabolism than a building block of life.

That is a complicated way of saying that work investigating the role of hydrothermal chemistry in an origins context should possibly be looking at higher temperatures, higher pressures, low water activities, and catalysts containing native metals, carbides, and minerals like magnetite. It is possible that efficient synthesis of amino acids and bases from $\mathrm{CO}_{2}$ and $\mathrm{N}_{2}$ requires conditions where both gases are reduced to an appreciable extent simultaneously. This does not mean that Haber-Bosch-like conditions $\left(500^{\circ} \mathrm{C}\right)$ need to be employed for prebiotic type synthesis, because there is no imperative to generate high yields or specificity from such experiments. It does, however, suggest that FeS, despite its unassailably essential role in the physiology of life, despite its unquestionable antiquity [153], and despite its unquestioned ability to generate thioesters from $\mathrm{CH}_{3} \mathrm{SH}$ and $\mathrm{CO}$ [159] might not be the right electron donor to get $\mathrm{CO}_{2}$ reduced in a hydrothermal context. Although $\mathrm{FeS}$ is crucial to make iron biologically accessible, and sulfur compounds were probably very important for the transition from thermal to chemical activation, catalysts that promote two-electron reactions fit better to the chemistry of carbon. We also need to consider the very real possibility that some reactions work better (or at all) at greater depth, products being transported by hydrothermal current to cooler environments near the surface where they can react under milder conditions (Figure 4), and where lower temperature reactions more similar to energetically coupled metabolism (as opposed to synthesis), such as those reported by Muchowska et al. [160] (although under acidic conditions) and Varma et al. [80], or oscillating thioester reactions such as those reported by Semenov et al. [161], come into play. Even at hydrothermal vents, in terms of catalysis, some reactions take place on certain surfaces at higher temperatures, others will only function at lower temperatures with different catalysts. In that sense, the sequence of reactions in the acetyl-CoA pathway [83] from electron bifurcation, to CO, to acyl metal bonds, to thioesters that yield acyl phosphates (Figure 5), which phosphorylate ADP to generate ATP, can be seen as the spatially condensed and enzymatically catalyzed version of a spontaneous geochemical process, the thermodynamic drive for which stems from the natural tendency of $\mathrm{CO}_{2}$ to be reduced with electrons from $\mathrm{H}_{2}$. That is, similar to the iron(II) carbonyl of hydrogenases, the chemical reactions of the acetyl-CoA pathway themselves are older than the enzymes that catalyze them.

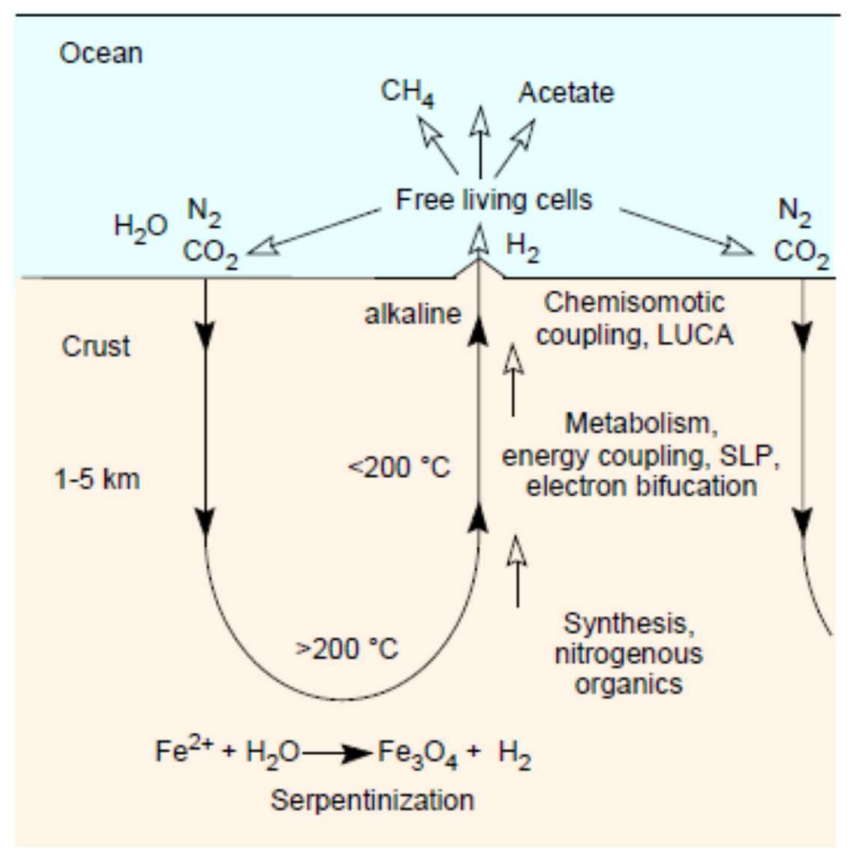

Figure 4. Possible processes at depth and at the ocean floor in serpentinizing systems. See text. 


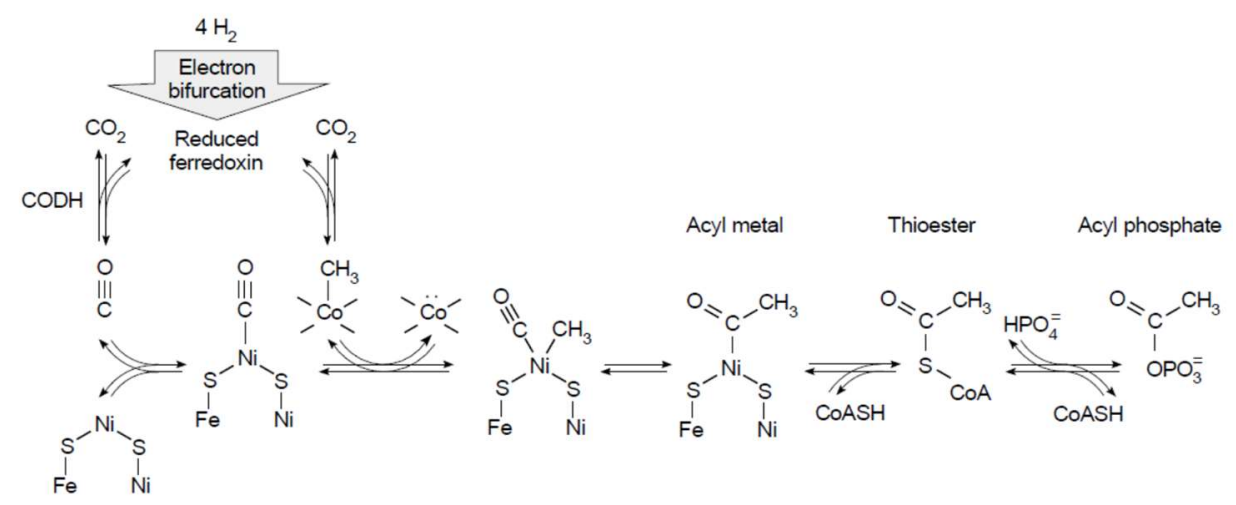

Figure 5. An ancient pathway. The diagram summarizes the biological energy conservation from ferredoxin to acyl phosphate in the acetyl-CoA pathway in an early evolution context $[23,78,112]$. Note that the reactions shown also occur without enzymes under suitable conditions [152]. See text. For an explanation of electron bifurcation see [106]. CODH: Carbon monoxide dehydrogenase.

Early papers on vents and life [1] voiced similar considerations about the possibility of different processes occurring at different depths. This became more evident as it became clear that serpentinization was relevant to synthesis at vent and origins [50]. A spectrum of processes across depths and conditions needs to be considered. And why, one might ask, have industrial chemists not already exhaustively explored the kinds of reactions sketched at the right of Figure 2? Reacting $\mathrm{H}_{2}, \mathrm{~N}_{2}$ and $\mathrm{CO}_{2}$ on $\mathrm{Fe}_{3} \mathrm{O}_{4}$ at temperatures needed for nitrogen reduction is not only Haber-Bosch expensive (energy intense), it is not going to generate any specific product. Chemists have not yet explored all kinds of conditions that might be interesting for prebiotic chemistry [162], the high-pressure-high-temperature reaction parameter space holds potential for investigation. Hydrothermal vents have been supporting microbial life for 3.5 billion years [163], perhaps because it arose there.

There also might be other parallels between bio- and geochemistry. For example, the formation of $\mathrm{Ni}_{3} \mathrm{Fe}$ is still a mystery, and it poses an energetic problem similar to flavin-based electron bifurcation: The electrons from $\mathrm{H}_{2}$ need to go energetically (far) uphill to reduce $\mathrm{Fe}^{2+}$ to $\mathrm{Fe}^{0}$ under the conditions in hydrothermal systems. Might there be a geochemical redox process akin to biological electron bifurcation, that is, might the reduction of $\mathrm{Fe}^{2+}$ to $\mathrm{Fe}^{0}$ via hydrogen be energetically coupled to (and financed by) $\mathrm{Ni}^{0}$ deposition? It would help to explain why native $\mathrm{Ni}$ and $\mathrm{Fe}$ are deposited together, and in the case of awaruite in a stoichiometry favoring $\mathrm{Ni}$, even though it is much rarer than $\mathrm{Fe}$ in serpentinizing systems.

Some of the organic compounds found on carbonaceous chondrites are apparently formed via FT type reactions [164]. FT type reactions in the presence of $\mathrm{NH}_{3}$ generate the familiar nucleobases, but at very low conversions (ca. $0.02 \%$ of product) and requiring short heating up to ca. $600{ }^{\circ} \mathrm{C}$ [164]. An old experiment [165] serves as a reminder: Heating three amino acids (combinations of glycine, alanine, valine, lysine, asparagine and glutamine) without water to temperatures between $160^{\circ} \mathrm{C}$ to $200^{\circ} \mathrm{C}$ for 4 to $6 \mathrm{~h}$ or to temperatures between $180^{\circ} \mathrm{C}$ to $350{ }^{\circ} \mathrm{C}$ for 1 to $2 \mathrm{~h}$ produces, inter alia, the compound shown in Figure 6.

There has to be something innately natural to the chemistry of life that its chemical constituents will assemble effortlessly when the right conditions and catalysts are found. Perhaps reducing $\mathrm{CO}_{2}$ and $\mathrm{N}_{2}$ under chemical industry conditions milder than Haber-Bosch, with catalysts derived from $\mathrm{H}_{2}$ and $\mathrm{Fe}_{3} \mathrm{O}_{4}$, will deliver a hydrothermal version of the Miller-Urey experiment, with a diversity of relevant nitrogenous compounds. This is an experiment that hydrothermal theories have been missing. The surface structure, morphology, facets, and impurities of catalysts should be also taken into account as crucial parameters. Concomitant reduction of $\mathrm{N}_{2}$ and $\mathrm{CO}_{2}$ might yield a diversity of compounds relevant to life more readily than adding $\mathrm{NH}_{3}$ to reduced carbon compounds. Regardless, by better 
understanding the sequence of chemical events within hydrothermal systems we should gain insights into catalysts that can further close the gap between rock-water-carbon interaction in vents, and life.

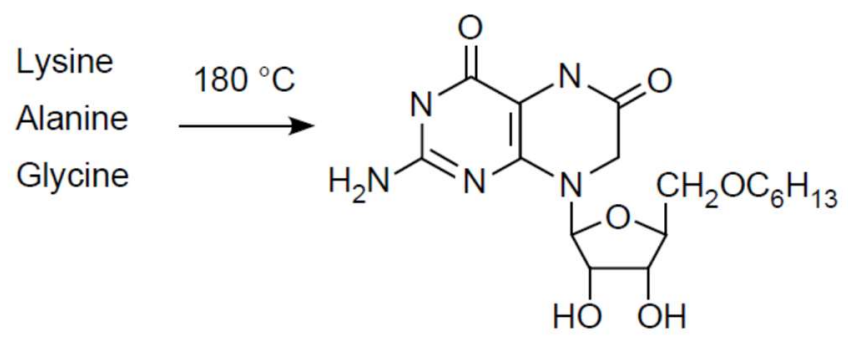

Figure 6. Pterin riboside from amino acids. One of the products obtained by Heinz et al. [165] without catalysts from dry heating of three amino acids is shown. Pterins are important cofactors in the acetyl-CoA pathway $[83,86,166]$. Note the $N$-glycosidic bond of the heterocyclic to ribose.

Funding: The authors thank the following agencies for funding: The Deutsche Forschungsgemeinschaft (TU 315/8-1 to HT and MA 1426/21-1 to WFM); the ERC (666053 to WFM and a StG to FLS); the VW Foundation (93 046 to WFM); the Wiener Wissenschaft und Technologiefonds (VRG15-007 to FLS); the National Science Foundation (OCE-1536702 to SQL); and the NASA Astrobiology Institute Cooperative Agreement (NNA15BB02A to TMM).

Acknowledgments: We thank Marcella Bonchio (Padua) and Joseph Moran (Strasbourg) for discussions.

Conflicts of Interest: The authors declare no conflict of interest.

\section{References}

1. Corliss, J.B.; Baross, J.A.; Hoffman, S.E. A hypothesis concerning the relationships between submarine hot springs and the origin of life on earth. Oceanol. Acta 1981, 59-69. Available online: http:/ / archimer.ifremer. fr/doc/00245/35661/34170.pdf (accessed on 22 September 2018).

2. Baross, J.A.; Hoffman, S.E. Submarine hydrothermal vents and associated gradient environments as sites for the origin and evolution of life. Orig. Life Evol. Biosph. 1985, 15, 327-345. [CrossRef]

3. Holm, N.G. Why are Hydrothermal Systems Proposed as Plausible Environments for the Origin of Life? In Marine Hydrothermal Systems and the Origin of Life; Holm, N.G., Ed.; Springer: Dordrecht, The Netherlands, 1992; pp. 5-14.

4. Nisbet, E.; Sleep, N.H. The habitat and nature of early life. Nature 2001, 409, 1083-1091. [CrossRef] [PubMed]

5. McCollom, T.M.; Seewald, J.S. Serpentinites, hydrogen, and life. Elements 2013, 9, 129-134. [CrossRef]

6. Russell, M.J.; Hall, A.J. The emergence of life from iron monosulphide bubbles at a submarine hydrothermal redox and pH front. J. Geol. Soc. 1997, 154, 377-402. [CrossRef]

7. Kelley, D.S.; Baross, J.A.; Delaney, J.R. Volcanoes, fluids, and life at mid-ocean ridge spreading centers. Annu. Rev. Earth Planet. Sci. 2002, 30, 385-491. [CrossRef]

8. Freeland, S.J.; Hurst, L.D. The genetic code is one in a million. J. Mol. Evol. 1998, 47, 238-248. [CrossRef] [PubMed]

9. Tashiro, T.; Ishida, A.; Hori, M.; Igisu, M.; Koike, M.; Méjean, P.; Takahata, N.; Sano, Y.; Komiya, T. Early trace of life from 3.95 Ga sedimentary rocks in Labrador, Canada. Nature 2017, 549, 516-518. [CrossRef] [PubMed]

10. Ueno, Y.; Yamada, K.; Yoshida, N.; Maruyama, S.; Isozaki, Y. Evidence from fluid inclusions for microbial methanogenesis in the early Archaean era. Nature 2006, 440, 516-519. [CrossRef] [PubMed]

11. Cleaves, H.J., II. The prebiotic geochemistry of formaldehyde. Precambrian Res. 2008, 164, 111-118. [CrossRef]

12. Patel, B.H.; Percivalle, C.; Ritson, D.J.; Duffy, C.D.; Sutherland, J.D. Common origins of RNA, protein and lipid precursors in a cyanosulfidic protometabolism. Nat. Chem. 2015, 7, 301-307. [CrossRef] [PubMed]

13. Russell, M.J.; Nitschke, W.; Branscomb, E. The inevitable journey to being. Philos. Trans. R. Soc. B Biol. Sci. 2013, 368, 20120254. [CrossRef] [PubMed]

14. Cockell, C.S. The origin and emergence of life under impact bombardment. Philos. Trans. R. Soc. B 2006, 362, 1845-1856. [CrossRef] [PubMed] 
15. Furukawa, Y.; Sekine, T.; Oba, M.; Kakegawa, T.; Nakazawa, H. Biomolecule formation by oceanic impacts on early Earth. Nat. Geosci. 2009, 2, 62-66. [CrossRef]

16. Russell, M. First Life. Am. Sci. 2006, 94, 32-39. [CrossRef]

17. Jackson, J.B. Natural $\mathrm{pH}$ gradients in hydrothermal alkali vents were unlikely to have played a role in the origin of life. J. Mol. Evol. 2016, 83, 1-11. [CrossRef] [PubMed]

18. Lane, N. Proton gradients at the origin of life. BioEssays 2017, 39, 1600217. [CrossRef] [PubMed]

19. Shock, E.L.; Helgeson, H.C. Calculation of the thermodynamic and transport properties of aqueous species at high pressures and temperatures: Correlation algorithms for ionic species and equation of state predictions to $5 \mathrm{~kb}$ and $1000^{\circ} \mathrm{C}$. Geochim. Cosmochim. Acta 1988, 52, 2009-2036. [CrossRef]

20. Shock, E.L. Geochemical constraints on the origin of organic compounds in hydrothermal systems. Orig. Life Evol. Biosph. 1990, 20, 331-367. [CrossRef]

21. Konn, C.; Charlou, J.L.; Holm, N.G.; Mousis, O. The production of methane, hydrogen, and organic compounds in ultramafic-hosted hydrothermal vents of the Mid-Atlantic Ridge. Astrobiology 2015, 15, 381-399. [CrossRef] [PubMed]

22. McCollom, T.M.; Sherwood Lollar, B.; Lacrampe-Couloume, G.; Seewald, J.S. The influence of carbon source on abiotic organic synthesis and carbon isotope fractionation under hydrothermal conditions. Geochim. Cosmochim. Acta 2010, 74, 2717-2740. [CrossRef]

23. Schrenk, M.O.; Brazelton, W.J.; Lang, S.Q. Serpentinization, carbon, and deep life. Rev. Mineral. Geochem. 2013, 75, 575-606. [CrossRef]

24. Martin, W.; Russell, M.J. On the origin of biochemistry at an alkaline hydrothermal vent. Philos. Trans. R. Soc. B Biol. Sci. 2007, 362, 1887-1925. [CrossRef] [PubMed]

25. Martin, W.; Baross, J.; Kelley, D.; Russell, M.J. Hydrothermal vents and the origin of life. Nat. Rev. Microbiol. 2008, 6, 805-814. [CrossRef] [PubMed]

26. Ragsdale, S.W. Nickel-based enzyme systems. J. Biol. Chem. 2009, 284, 18571-18575. [CrossRef] [PubMed]

27. Can, M.; Armstrong, F.A.; Ragsdale, S.W. Structure, function, and mechanism of the nickel metalloenzyme, CO dehydrogenase, and acetyl-CoA synthase. Bioinorg. Enzymol. 2014, 114, 4149-4174. [CrossRef] [PubMed]

28. Lancaster, K.M.; Roemelt, M.; Ettenhuber, P.; Hu, Y.; Ribbe, M.W.; Neese, F.; Bergmann, U.; DeBeer, S. X-ray emission spectroscopy evidences a central carbon in the nitrogenase iron-molybdenum cofactor. Science 2011, 334, 974-977. [CrossRef] [PubMed]

29. Spatzal, T.; Aksoyoglu, M.; Zhang, L.; Andrade, S.L.A.; Schleicher, E.; Weber, S.; Rees, D.C.; Einsle, O. Evidence for interstitial carbon in nitrogenase FeMo cofactor. Science 2011, 334, 940. [CrossRef] [PubMed]

30. Wei, J.; Ge, Q.; Yao, R.; Wen, Z.; Fang, C.; Guo, L.; Xu, H.; Sun, J. Directly converting $\mathrm{CO}_{2}$ into a gasoline fuel. Nat. Commun. 2017, 8, 15174. [CrossRef] [PubMed]

31. Ertl, G. Primary steps in catalytic synthesis of ammonia. J. Vac. Sci. Technol. A Vac. Surf. Films 1983, 1, 1247-1253. [CrossRef]

32. Kandemir, T.; Schuster, M.E.; Senyshyn, A.; Behrens, M.; Schlögl, R. The Haber-Bosch process revisited: On the real structure and stability of "ammonia iron" under working conditions. Angew. Chem. Int. Ed. 2013, 52, 12723-12726. [CrossRef] [PubMed]

33. McCollom, T.M.; Seewald, J.S. Abiotic synthesis of organic compounds in deep-sea hydrothermal environments. Chem. Rev. 2007, 107, 382-401. [CrossRef] [PubMed]

34. Hennet, R.J.-C.; Holm, N.G.; Engel, M.H. Abiotic synthesis of amino acids under hydrothermal conditions and the origin of life: A perpetual phenomenon? Naturwissenschaften 1992, 79, 361-365. [CrossRef] [PubMed]

35. Shock, E.; Schulte, M.D. Organic synthesis during fluid mixing in hydrothermal systems. J. Geophys. Res. 1998, 103, 28513-28527. [CrossRef]

36. Amend, J.P.; Shock, E.L. Energetics of amino acid synthesis in hydrothermal ecosystems. Science 1998, 281, 1659-1662. [CrossRef] [PubMed]

37. Amend, J.P.; McCollom, T.M. Energetics of biomolecule synthesis on early Earth. In Chemical Evolution II: From the Origins of Life to Modern Soc; ACS Publications: Washington, DC, USA, 2009; pp. 63-94.

38. Sleep, N.H.; Bird, D.K.; Pope, E.C. Serpentinite and the dawn of life. Philos. Trans. R. Soc. B Biol. Sci. 2011, 366, 2857-2869. [CrossRef] [PubMed]

39. Arndt, N.T.; Nisbet, E.G. Processes on the young Earth and the habitats of early life. Annu. Rev. Earth Planet. Sci. 2012, 40, 521-549. [CrossRef] 
40. Zahnle, K.; Arndt, N.; Cockell, C.; Halliday, A.; Nisbet, E.; Selsis, F.; Sleep, N.H. Emergence of a habitable planet. Space Sci. Rev. 2007, 129, 35-78. [CrossRef]

41. Dasgupta, R. Ingassing, storage, and outgassing of terrestrial carbon through geologic time. Rev. Mineral. Geochem. 2013, 75, 183-229. [CrossRef]

42. Etiope, G.; Schoell, M. Abiotic gas: Atypical, but not rare. Elements 2014, 10, 291-296. [CrossRef]

43. Bottke, W.F.; Norman, M.D. The late heavy bombardment. Annu. Rev. Earth Planet. Sci. 2017, 45, 619-647. [CrossRef]

44. Litasov, K.D.; Shatskiy, A.F. Composition of the Earth's core: A review. Russ. Geol. Geophys. 2016, 57, $22-46$. [CrossRef]

45. Kasting, J.F.; Holm, N.G. What determines the volume of the oceans? Earth Planet. Sci. Lett. 1992, 109, 507-515. [CrossRef]

46. Westall, F.; Brack, A. The importance of water for life. Space Sci. Rev. 2018, 214, 1-23. [CrossRef]

47. Korenaga, J.; Planavsky, N.J.; Evans, D.A.D. Global water cycle and the coevolution of the Earth's interior and surface environment. Philos. Trans. R. Soc. A 2017, 375, 20150393. [CrossRef] [PubMed]

48. McCollom, T.M.; Bach, W. Thermodynamic constraints on hydrogen generation during serpentinization of ultramafic rocks. Geochim. Cosmochim. Acta 2009, 73, 856-875. [CrossRef]

49. Klein, F.; Bach, W.; McCollom, T.M. Compositional controls on hydrogen generation during serpentinization of ultramafic rocks. Lithos 2013, 178, 55-69. [CrossRef]

50. Holm, N.G. Hydrothermal activity and the volume of the oceans. Deep. Res. Part II Top. Stud. Oceanogr. 1996, 43, 47-52. [CrossRef]

51. Russell, M.J.; Hall, A.J.; Martin, W. Serpentinization as a source of energy at the origin of life. Geobiology 2010, 8, 355-371. [CrossRef] [PubMed]

52. Holm, N.G.; Oze, C.; Mousis, O.; Waite, J.H.; Guilbert-Lepoutre, A. Serpentinization and the formation of $\mathrm{H}_{2}$ and $\mathrm{CH}_{4}$ on celestial bodies (planets, moons, comets). Astrobiology 2015, 15, 587-600. [CrossRef] [PubMed]

53. Klein, F.; Bach, W. Fe-Ni-Co-O-S phase relations in peridotite-seawater interactions. J. Petrol. 2009, 50, 37-59. [CrossRef]

54. Foustoukos, D.I.; Bizimis, M.; Frisby, C.; Shirey, S.B. Redox controls on Ni-Fe-PGE mineralization and Re/Os fractionation during serpentinization of abyssal peridotite. Geochim. Cosmochim. Acta 2015, 150, 11-25. [CrossRef]

55. Sleep, N.H.; Meibom, A.; Fridriksson, T.; Coleman, R.G.; Bird, D.K. $\mathrm{H}_{2}$-rich fluids from serpentinization: Geochemical and biotic implications. Proc. Natl. Acad. Sci. USA 2004, 101, 12818-12823. [CrossRef] [PubMed]

56. Lang, S.Q.; Früh-Green, G.; Bernasconi, S.M.; Brazelton, W.J.; Schrenk, M.O.; McGonigle, J.M. Deeply-sourced formate fuels sulfate reducers but not methanogens at Lost City hydrothermal field. Sci. Rep. 2018, 8, 755. [CrossRef] [PubMed]

57. Janecky, D.R.; Seyfried, W.E. Hydrothermal serpentinization of peridotite within the oceanic crust: Experimental investigations of mineralogy and major element chemistry. Geochim. Cosmochim. Acta 1986, 50, 1357-1378. [CrossRef]

58. Palandri, J.L.; Reed, M.H. Geochemical models of metasomatism in ultramafic systems: Serpentinization, rodingitization, and sea floor carbonate chimney precipitation. Geochim. Cosmochim. Acta 2004, 68, 1115-1133. [CrossRef]

59. Charlou, J.L.; Donval, J.P.; Fouquet, Y.; Jean-Baptiste, P.; Holm, N. Geochemistry of high $\mathrm{H}_{2}$ and $\mathrm{CH}_{4}$ vent fluids issuing from ultramafic rocks at the Rainbow hydrothermal field ( $\left.36^{\circ} 14^{\prime} \mathrm{N}, \mathrm{MAR}\right)$. Chem. Geol. 2002, 191, 345-359. [CrossRef]

60. Kelley, D.S.; Karson, J.A.; Früh-Green, G.L.; Yoerger, D.R.; Shank, T.M.; Butterfield, D.A.; Hayes, J.M.; Schrenk, M.O.; Olson, E.J.; Proskurowski, G.; et al. A serpentinite-hosted ecosystem: The Lost City Hydrothermal Field. Science 2005, 307, 1428-1434. [CrossRef] [PubMed]

61. Seyfried, W.E.; Foustoukos, D.I.; Fu, Q. Redox evolution and mass transfer during serpentinization: An experimental and theoretical study at $200{ }^{\circ} \mathrm{C}, 500$ bar with implications for ultramafic-hosted hydrothermal systems at Mid-Ocean Ridges. Geochim. Cosmochim. Acta 2007, 71, 3872-3886. [CrossRef]

62. McCollom, T.M.; Klein, F.; Robbins, M.; Moskowitz, B.; Berquó, T.S.; Jöns, N.; Bach, W.; Templeton, A. Temperature trends for reaction rates, hydrogen generation, and partitioning of iron during experimental serpentinization of olivine. Geochim. Cosmochim. Acta 2016, 181, 175-200. [CrossRef] 
63. Ueda, H.; Shibuya, T.; Sawaki, Y.; Saitoh, M.; Takai, K.; Maruyama, S. Reactions between komatiite and $\mathrm{CO}_{2}$-rich seawater at 250 and $350{ }^{\circ} \mathrm{C}, 500$ bars: Implications for hydrogen generation in the Hadean seafloor hydrothermal system. Prog. Earth Planet. Sci. 2016, 3, 35. [CrossRef]

64. McCollom, T.M.; Seewald, J.S. A reassessment of the potential for reduction of dissolved $\mathrm{CO}_{2}$ to hydrocarbons during serpentinization of olivine. Geochim. Cosmochim. Acta 2001, 65, 3769-3778. [CrossRef]

65. Früh-Green, G.L.; Connolly, J.A.D.; Plas, A.; Kelley, D.S.; Grobety, B. Serpentinization of oceanic peridotites: Implications for geochemical cycles and biological activity. In The Subseafloor Biosphere at Mid-Ocean Ridges Geophysical Monograph Series 144; Wilcock, W.S.D., Delong, E.F., Kelley, D.S., Baross, J.A., Craig, C.S., Eds.; American Geophysical Union: Washington, DC, USA, 2004; pp. 119-136.

66. Frost, R. On the stability of sulfides, oxides, and native metals in serpentinite. J. Petrol. 1985, 26, 31-63. [CrossRef]

67. Alt, J.C.; Shanks, W.C. Sulfur in serpentinized oceanic peridotites: Serpentinization processes and microbial sulfate reduction. J. Geophys. Res. Solid Earth 1998, 103, 9917-9929. [CrossRef]

68. McCollom, T.M. Abiotic methane formation during experimental serpentinization of olivine. Proc. Natl. Acad. Sci. USA 2016, 113, 13965-13970. [CrossRef] [PubMed]

69. Früh-Green, G.L.; Kelley, D.S.; Bernasconi, S.M.; Karson, J.A.; Ludwig, K.A.; Butterfield, D.A.; Boschi, C.; Proskurowski, G. 30,000 Years of hydrothermal activity at the Lost City vent field. Science 2003, 301, 495-498. [CrossRef] [PubMed]

70. Ludwig, K.A.; Shen, C.C.; Kelley, D.S.; Cheng, H.; Edwards, R.L. U-Th systematics and 230th ages of carbonate chimneys at the Lost City Hydrothermal Field. Geochim. Cosmochim. Acta 2011, 75, 1869-1888. [CrossRef]

71. Proskurowski, G.; Lilley, M.D.; Seewald, J.S.; Früh-Green, G.L.; Olson, E.J.; Lupton, J.E.; Sylva, S.P.; Kelley, D.S. Abiogenic hydrocarbon production at Lost City hydrothermal field. Science 2008, 319, 319-607. [CrossRef] [PubMed]

72. Lang, S.Q.; Butterfield, D.A.; Schulte, M.; Kelley, D.S.; Lilley, M.D. Elevated concentrations of formate, acetate and dissolved organic carbon found at the Lost City hydrothermal field. Geochim. Cosmochim. Acta 2010, 74, 941-952. [CrossRef]

73. Holm, N.G.; Charlou, J.L. Initial indications of abiotic formation of hydrocarbons in the Rainbow ultramafic hydrothermal system, Mid-Atlantic Ridge. Earth Planet. Sci. Lett. 2001, 191, 1-8. [CrossRef]

74. McDermott, J.M.; Seewald, J.S.; German, C.R.; Sylva, S.P. Pathways for abiotic organic synthesis at submarine hydrothermal fields. Proc. Natl. Acad. Sci. USA 2015, 112, 7668-7672. [CrossRef] [PubMed]

75. Etiope, G.; Sherwood Lollar, B. Abiotic methane on Earth. Rev. Geophys. 2013, 51, 276-299. [CrossRef]

76. Horita, J.; Berndt, M.E. Abiogenic methane formation and isotopic fractionation under hydrothermal conditions. Sci. Rep. 1999, 285, 1055-1057. [CrossRef]

77. Heinen, W.; Lauwers, A. The iron-sulfur world and the origins of life: Abiotic thiol synthesis from metallic iron, $\mathrm{H}_{2} \mathrm{~S}$ and $\mathrm{CO}_{2}$; a comparison of the thiol generating $\mathrm{FeS} / \mathrm{HCl}\left(\mathrm{H}_{2} \mathrm{~S}\right) / \mathrm{CO}_{2}$-system and its $\mathrm{Fe}^{0} / \mathrm{H}_{2} \mathrm{~S} / \mathrm{CO}_{2}$-counterpart. Proc. K. Ned. Akad. Van Wet. 1997, 100, 11-25.

78. Guan, G.; Kida, T.; Ma, T.; Kimura, K.; Abe, E.; Yoshida, A. Reduction of aqueous $\mathrm{CO}_{2}$ at ambient temperature using zero-valent iron-based composites. Green Chem. 2003, 5, 630. [CrossRef]

79. He, C.; Tian, G.; Liu, Z.; Feng, S. A mild hydrothermal route to fix carbon dioxide to simple carboxylic acids. Org. Lett. 2010, 12, 649-651. [CrossRef] [PubMed]

80. Varma, S.J.; Muchowska, K.B.; Chatelain, P.; Moran, J. Native iron reduces $\mathrm{CO}_{2}$ to intermediates and endproducts of the acetyl-CoA pathway. Nat. Ecol. Evol. 2018, 2, 1019-1024. [CrossRef] [PubMed]

81. Thauer, R.K.; Kaster, A.K.; Seedorf, H.; Buckel, W.; Hedderich, R. Methanogenic archaea: Ecologically relevant differences in energy conservation. Nat. Rev. Microbiol. 2008, 6, 579-591. [CrossRef] [PubMed]

82. Müller, V. Energy conservation in acetogenic bacteria. Appl. Environ. Microbiol. 2003, 69, 6345-6353. [CrossRef] [PubMed]

83. Fuchs, G. Alternative pathways of carbon dioxide fixation: Insights into the early evolution of life? Annu. Rev. Microbiol. 2011, 65, 631-658. [CrossRef] [PubMed]

84. Berg, I.A.; Kockelkorn, D.; Buckel, W.; Fuchs, G. A 3-hydroxypropionate/4-hydroxybutyrate autotrophic carbon dioxide assimilation pathway in archaea. Science 2007, 318, 1782-1786. [CrossRef] [PubMed]

85. Fuchs, G. $\mathrm{CO}_{2}$ fixation in acetogenic bacteria: Variations on a theme. FEMS Microbiol. Lett. 1986, 39, $181-213$. [CrossRef] 
86. Sousa, F.L.; Martin, W.F. Biochemical fossils of the ancient transition from geoenergetics to bioenergetics in prokaryotic one carbon compound metabolism. Biochim. Biophys. Acta Bioenerg. 2014, 1837, $964-981$. [CrossRef] [PubMed]

87. Weiss, M.C.; Sousa, F.L.; Mrnjavac, N.; Neukirchen, S.; Roettger, M.; Nelson-Sathi, S.; Martin, W.F. The physiology and habitat of the last universal common ancestor. Nat. Microbiol. 2016, 1, 16116. [CrossRef] [PubMed]

88. Weiss, M.C.; Preiner, M.; Xavier, J.C.; Zimorski, V.; Martin, F. The last universal common ancestor between ancient Earth chemistry and the onset of genetics. PLoS Genet. 2018, 14, e1007518. [CrossRef] [PubMed]

89. Früh-Green, G.L.; Orcutt, B.N.; Green, S.L.; Cotterill, C.; Morgan, S.; Akizawa, N.; Bayrakci, G.; Behrmann, J.-H.; Boschi, C.; Brazelton, W.J.; et al. Northern sites. Proc. Int. Ocean Discov. Progr. 2017, 357. [CrossRef]

90. Smirnov, A.; Hausner, D.; Laffers, R.; Strongin, D.R.; Schoonen, M.A.A. Abiotic ammonium formation in the presence of Ni-Fe metals and alloys and its implications for the Hadean nitrogen cycle. Geochem. Trans. 2008, 9, 5-20. [CrossRef] [PubMed]

91. Brandes, J.A.; Boctor, N.Z.; Cody, G.D.; Cooper, B.A.; Hazen, R.M.; Yoder, H.S. Abiotic nitrogen reduction on the early Earth. Nature 1998, 395, 365-367. [CrossRef] [PubMed]

92. Dörr, M.; Käßbohrer, J.; Grunert, R.; Kreisel, G.; Brand, W.A.; Werner, R.A.; Geilmann, H.; Apfel, C.; Robl, C.; Weigand, W. A possible prebiotic formation of ammonia from dinitrogen on iron sulfide surfaces. Angew. Chem. Int. Ed. 2003, 42, 1540-1543. [CrossRef] [PubMed]

93. Holm, N.G.; Neubeck, A. Reduction of nitrogen compounds in oceanic basement and its implications for HCN formation and abiotic organic synthesis. Geochem. Trans. 2009, 10, 9. [CrossRef] [PubMed]

94. Bradley, A.S. The sluggish speed of making abiotic methane. Proc. Natl. Acad. Sci. USA 2016, 113, 13944-13946. [CrossRef] [PubMed]

95. Wang, D.T.; Reeves, E.P.; McDermott, J.M.; Seewald, J.S.; Ono, S. Clumped isotopologue constraints on the origin of methane at seafloor hot springs. Geochim. Cosmochim. Acta 2018, 223, 141-158. [CrossRef]

96. Seewald, J.S.; Zolotov, M.Y.; McCollom, T. Experimental investigation of single carbon compounds under hydrothermal conditions. Geochim. Cosmochim. Acta 2006, 70, 446-460. [CrossRef]

97. Miller, H.M.; Mayhew, L.E.; Ellison, E.T.; Kelemen, P.; Kubo, M.; Templeton, A.S. Low temperature hydrogen production during experimental hydration of partially-serpentinized dunite. Geochim. Cosmochim. Acta 2017, 209, 161-183. [CrossRef]

98. Oparin, A.I. Origin of Life; Dover Publications: New York, NY, USA, 1936; ISBN 0-486-60213-3.

99. Dictor, R.A.; Bell, A.T. Fischer-Tropsch synthesis over reduced and unreduced iron oxide catalysts. J. Catal. 1986, 97, 121-136. [CrossRef]

100. Wu, B.; Tian, L.; Xiang, H.; Zhang, Z.; Li, Y.W. Novel precipitated iron Fischer-Tropsch catalysts with $\mathrm{Fe}_{3} \mathrm{O}_{4}$ coexisting with $\alpha$-Fe2O3. Catal. Lett. 2005, 102, 211-218. [CrossRef]

101. McCollom, T.M. Miller-Urey and beyond: What have we learned about prebiotic organic synthesis reactions in the past 60 years? Annu. Rev. Earth Planet. Sci. 2013, 41, 207-229. [CrossRef]

102. Holm, N.G.; Dumont, M.; Ivarsson, M.; Konn, C. Alkaline fluid circulation in ultramafic rocks and formation of nucleotide constituents: A hypothesis. Geochem. Trans. 2006, 7, 14-16. [CrossRef] [PubMed]

103. McCollom, T.M. Laboratory simulations of abiotic hydrocarbon formation in Earth's deep subsurface. Rev. Mineral. Geochem. 2013, 75, 467-494. [CrossRef]

104. Porosoff, M.D.; Kattel, S.; Li, W.; Liu, P.; Chen, J.G. Identifying trends and descriptors for selective $\mathrm{CO}_{2}$ conversion to CO over transition metal carbides. Chem. Commun. 2015, 51, 6988. [CrossRef] [PubMed]

105. Rodriguez, J.A.; Liu, P.; Stacchiola, D.J.; Senanayake, S.D.; White, M.G.; Chen, J.G. Hydrogenation of $\mathrm{CO}_{2}$ to methanol: Importance of metal-oxide and metal-carbide interfaces in the activation of $\mathrm{CO}_{2}$. ACS Catal. 2015, 5, 6696-6706. [CrossRef]

106. Riedel, T.; Schulz, H.; Schaub, G.; Jun, K.W.; Hwang, J.S.; Lee, K.W. Fischer-Tropsch on iron with $\mathrm{H}_{2} / \mathrm{CO}$ and $\mathrm{H}_{2} / \mathrm{CO}_{2}$ as synthesis gases: The episodes of formation of the Fischer-Tropsch regime and construction of the catalyst. Top. Catal. 2003, 26, 41-54. [CrossRef]

107. Pichler, H. Twenty-five years of synthesis of gasoline by catalytic conversion of carbon monoxide and hydrogen. In Advances in Catalysis; Frankenburg, W., Rideal, E., Komarewsky, V., Eds.; Academic Press Inc.: New York, NY, USA, 1952; p. 271. ISBN 9780120078042.

108. Dry, M.E. The Fischer-Tropsch process: 1950-2000. Catal. Today 2002, 71, 227-241. [CrossRef] 
109. Goodrich, C.A.; Bird, J.M. Formation of iron-carbon alloys in basaltic magma at Uivaq, Disko Island: The role of carbon in mafic magmas. J. Geol. 1985, 93, 475-492. [CrossRef]

110. Shi, N.; Bai, W.; Li, G.; Xiong, M.; Fang, Q.; Yang, J.; Ma, Z.; Rong, H. Yarlongite: A new metallic carbide mineral. Acta Geol. Sin. 2008, 83, 52-56. [CrossRef]

111. Horita, J.; Polyakov, V.B. Carbon-bearing iron phases and the carbon isotope composition of the deep Earth. Proc. Natl. Acad. Sci. USA 2015, 112, 31-36. [CrossRef] [PubMed]

112. Chen, Q.W.; Bahnemann, D.W. Reduction of carbon dioxide by magnetite: Implications for the primordial synthesis of organic molecules. J. Am. Chem. Soc. 2000, 122, 970-971. [CrossRef]

113. Russell, M.J.; Martin, W. The rocky roots of the acetyl-CoA pathway. Trends Biochem. Sci. 2004, $29,358-363$. [CrossRef] [PubMed]

114. Buckel, W.; Thauer, R.K. Flavin-based electron bifurcation, ferredoxin, flavodoxin, and anaerobic respiration with protons (Ech) or NAD+(Rnf) as electron acceptors: A historical review. Front. Microbiol. 2018, 9, 401. [CrossRef] [PubMed]

115. Schuchmann, K.; Müller, V. Direct and reversible hydrogenation of $\mathrm{CO}_{2}$ to formate by a bacterial carbon dioxide reductase. Science 2013, 342, 1382-1385. [CrossRef] [PubMed]

116. Herrmann, G.; Jayamani, E.; Mai, G.; Buckel, W. Energy conservation via electron-transferring flavoprotein in anaerobic bacteria. J. Bacteriol. 2008, 190, 784-791. [CrossRef] [PubMed]

117. Müller, V.; Chowdhury, N.P.; Basen, M. Electron bifurcation: A long- hidden energy-coupling mechanism. Annu. Rev. Microbiol. 2018, 72, 331-353. [CrossRef] [PubMed]

118. Kaster, A.-K.; Moll, J.; Parey, K.; Thauer, R.K. Coupling of ferredoxin and heterodisulfide reduction via electron bifurcation in hydrogenotrophic methanogenic archaea. Proc. Natl. Acad. Sci. USA 2011, 108, 2981-2986. [CrossRef] [PubMed]

119. Mall, A.; Sobotta, J.; Huber, C.; Tschirner, C.; Kowarschik, S.; Bačnik, K.; Mergelsberg, M.; Boll, M.; Hügler, M.; Eisenreich, W.; et al. Reversibility of citrate synthase allows autotrophic growth of a thermophilic bacterium. Science 2018, 359, 563-567. [CrossRef] [PubMed]

120. Nunoura, T.; Chikaraishi, Y.; Izaki, R.; Suwa, T.; Sato, T.; Harada, T.; Mori, K.; Kato, Y.; Miyazaki, M.; Shimamura, S.; et al. A primordial and reversible TCA cycle in a facultatively chemolithoautotrophic thermophile. Science 2018, 359, 559-563. [CrossRef] [PubMed]

121. 1Martin, W.F.; Thauer, R.K. Energy in ancient metabolism. Cell 2017, 168, 953-955. [CrossRef] [PubMed]

122. Xavier, J.C.; Preiner, M.; Martin, W.F. Something special about CO. FEBS J. 2018, in press. [CrossRef]

123. Dos Santos, P.C.; Igarashi, R.Y.; Lee, H.; Hoffman, B.M.; Seefeldt, L.C.; Dean, D.R. Substrate interactions with the nitrogenase active site. Acc. Chem. Res. 2005, 38, 208-214. [CrossRef] [PubMed]

124. Burgess, B.K.; Lowe, D.J. Mechanism of molybdenum nitrogenase. Chem. Rev. 1996, 96, 2983-3011. [CrossRef] [PubMed]

125. Zhang, L.; Kaiser, J.T.; Meloni, G.; Yang, K.-Y.; Spatzal, T.; Andrade, S.L.A.; Einsle, O.; Howard, J.B.; Rees, D.C. The 16th Fe in the nitrogenase MoFe-protein. Angew. Chem. Int. Ed. 2013, 52, 10529-10532. [CrossRef] [PubMed]

126. Buckel, W.; Hetzel, M.; Kim, J. ATP-driven electron transfer in enzymatic radical reactions. Curr. Opin. Chem. Biol. 2004, 8, 462-467. [CrossRef] [PubMed]

127. Wiig, J.A.; Hu, Y.; Ribbe, M.W. Refining the pathway of carbide insertion into the nitrogenase M-cluster. Nat. Commun. 2015, 6, 8034. [CrossRef] [PubMed]

128. Lee, C.C.; Hu, Y.; Ribbe, M.W. Insights into hydrocarbon formation by nitrogenase cofactor homologs. MBio 2015, 6, e00307-15. [CrossRef] [PubMed]

129. Boyd, E.S.; Peters, J.W. New insights into the evolutionary history of biological nitrogen fixation. Front. Microbiol. 2013, 4, 201. [CrossRef] [PubMed]

130. Anderson, J.S.; Rittle, J.; Peters, J.C. Catalytic conversion of nitrogen to ammonia by an iron model complex. Nature 2013, 501, 84-87. [CrossRef] [PubMed]

131. Martin, W.F. Hydrogen, metals, bifurcating electrons, and proton gradients: The early evolution of biological energy conservation. FEBS Lett. 2012, 586, 485-493. [CrossRef] [PubMed]

132. Williams, T.A.; Szöllösi, G.J.; Spang, A.; Foster, P.G.; Heaps, S.E.; Boussau, B.; Ettema, T.J.G.; Embley, T.M. Integrative modeling of gene and genome evolution roots the archaeal tree of life. Proc. Natl. Acad. Sci. USA 2017, 114, E4602-E4611. [CrossRef] [PubMed] 
133. Takami, H.; Noguchi, H.; Takaki, Y.; Uchiyama, I.; Toyoda, A.; Nishi, S.; Chee, G.; Arai, W.; Nunoura, T.; Itoh, T.; et al. A deeply branching thermophilic bacterium with an ancient acetyl-CoA pathway dominates a subsurface ecosystem. PLoS ONE 2012, 7, e30559. [CrossRef] [PubMed]

134. Martin, W.F.; Bryant, D.A.; Beatty, J.T. A physiological perspective on the origin and evolution of photosynthesis. FEMS Microbiol. Rev. 2018, 42, 205-231. [CrossRef] [PubMed]

135. Chapelle, F.H.; Neill, K.O.; Bradley, P.M.; Methe, B.A.; Ciufo, S.A.; Knobel, L.L.; Lovley, D.R. A hydrogen-based subsurface microbial community dominated by methanogens. Nature 2002, 415, 312-315. [CrossRef] [PubMed]

136. Lever, M.A.; Rouxel, O.; Alt, J.C.; Shimizu, N.; Ono, S.; Coggon, R.M.; Shanks, W.C.; Lapham, L.; Elvert, M.; Prieto-Mollar, X.; et al. Evidence for microbial carbon and sulfur cycling in deeply buried ridge flank basalt. Science 2013, 339, 1305-1308. [CrossRef] [PubMed]

137. Reeves, E.P.; Mcdermott, J.M.; Seewald, J.S. The origin of methanethiol in midocean ridge hydrothermal fluids. Proc. Natl. Acad. Sci. USA 2014, 111, 5474-5479. [CrossRef] [PubMed]

138. Schrenk, M.O.; Kelley, D.S.; Bolton, S.A.; Baross, J.A. Low archaeal diversity linked to subseafloor geochemical processes at the Lost City Hydrothermal Field, Mid-Atlantic Ridge. Environ. Microbiol. 2004, 6, 1086-1095. [CrossRef] [PubMed]

139. Brazelton, W.J.; Schrenk, M.O.; Kelley, D.S.; Baross, J.A. Methane- and sulfur-metabolizing microbial communities dominate the Lost City Hydrothermal Field ecosystem. Appl. Environ. Microbiol. 2006, 72, 6257-6270. [CrossRef] [PubMed]

140. Whitman, W.B.; Coleman, D.C.; Wiebe, W.J. Prokaryotes: The unseen majority. Proc. Natl. Acad. Sci. USA 1998, 95, 6578-6583. [CrossRef] [PubMed]

141. Bar-On, Y.M.; Phillips, R.; Milo, R. The biomass distribution on Earth. Proc. Natl. Acad. Sci. USA 2018, 115, 6506-6511. [CrossRef] [PubMed]

142. Heberling, C.; Lowell, R.P.; Liu, L.; Fisk, M.R. Extent of the microbial biosphere in the oceanic crust. Geochem. Geophys. Geosyst. 2010, 11. [CrossRef]

143. Milucka, J.; Ferdelman, T.G.; Polerecky, L.; Franzke, D.; Wegener, G.; Schmid, M.; Lieberwirth, I.; Wagner, M.; Widdel, F.; Kuypers, M.M.M. Zero-valent sulphur is a key intermediate in marine methane oxidation. Nature 2012, 491, 541-546. [CrossRef] [PubMed]

144. Miller, S.L.; Bada, J.L. Submarine hot springs and the origin of life. Nature 1988, 334, 609-611. [CrossRef] [PubMed]

145. Kelley, D.S.; Karson, J.A.; Blackman, D.K.; Früh-Green, G.L.; Butterfield, D.A.; Lilley, M.D.; Olson, E.J.; Schrenk, M.O.; Roe, K.K.; Lebon, G.T.; et al. An off-axis hydrothermal vent field near the Mid-Atlantic Ridge at 30 degrees N. Nature 2001, 412, 145-149. [CrossRef] [PubMed]

146. Benner, S.A.; Kim, H.-J.; Carrigan, M.A. Asphalt, water, and the prebiotic synthesis of ribose, ribonucleosides, and RNA. Acc. Chem. Res. 2012, 45, 2025-2034. [CrossRef] [PubMed]

147. Ricardo, A.; Carrigan, M.A.; Olcott, A.N.; Benner, S.A. Borate minerals stabilize ribose. Science 2004, $303,196$. [CrossRef] [PubMed]

148. Schönheit, P.; Buckel, W.; Martin, W.F. On the origin of heterotrophy. Trends Microbiol. 2016, 24, $12-25$. [CrossRef] [PubMed]

149. Stouthamer, A.H. Energy-yielding pathways. In The Bacteria Vol 6; Gunsalus, I.C., Ed.; Academic Press: New York, NY, USA, 1978; pp. 389-462.

150. Baross, J.A.; Martin, W.F. The ribofilm as a concept for life's origins. Cell 2015, 162, 13-15. [CrossRef] [PubMed]

151. Goldford, J.E.; Hartman, H.; Smith, T.F.; Segrè, D. Remnants of an ancient metabolism without phosphate. Cell 2017, 168, 1126-1134.e9. [CrossRef] [PubMed]

152. Goldford, J.E.; Segrè, D. Modern views of ancient metabolic networks. Curr. Opin. Syst. Biol. 2018, 8, 117-124. [CrossRef]

153. Dayhoff, M.O.; Eck, R.V. Evolution of the structure of ferredoxin based on surviving relics of primitive amino acid sequences. Science 1966, 152, 363-366. [CrossRef]

154. Wächtershäuser, G. Before enzymes and templates: Theory of surface metabolism. Microbiol. Rev. 1988, 52, 452-484. [PubMed] 
155. Thauer, R.K.; Kaster, A.-K.; Goenrich, M.; Schick, M.; Hiromoto, T.; Shima, S. Hydrogenases from methanogenic archaea, nickel, a novel cofactor, and $\mathrm{H}_{2}$ storage. Annu. Rev. Biochem. 2010, 79, 507-536. [CrossRef] [PubMed]

156. Thauer, R.K. Hydrogenases and the global $\mathrm{H}_{2}$ cycle. Eur. J. Inorg. Chem. 2011, 2011, 919-921. [CrossRef]

157. Wächtershäuser, G. Groundworks for an evolutionary biochemistry: The iron-sulphur world. Prog. Biophys. Mol. Biol. 1992, 58, 85-201. [CrossRef]

158. Huber, C.; Eisenreich, W.; Wächtershäuser, G. Synthesis of $\alpha$-amino and $\alpha$-hydroxy acids under volcanic conditions: Implications for the origin of life. Tetrahedron Lett. 2010, 51, 1069-1071. [CrossRef]

159. Huber, C.; Wächtershäuser, G. Activated acetic acid by carbon fixation on (Fe,Ni)S under primordial conditions. Science 1997, 276, 245-248. [CrossRef] [PubMed]

160. Muchowska, K.B.; Varma, S.J.; Chevallot-Beroux, E.; Lethuillier-Karl, L.; Li, G.; Moran, J. Metals promote sequences of the reverse Krebs cycle. Nat. Ecol. Evol. 2017, 1, 1716-1721. [CrossRef] [PubMed]

161. Semenov, S.N.; Kraft, L.J.; Ainla, A.; Zhao, M.; Baghbanzadeh, M.; Campbell, V.E.; Kang, K.; Fox, J.M.; Whitesides, G.M. Autocatalytic, bistable, oscillatory networks of biologically relevant organic reactions. Nature 2016, 537, 656-660. [CrossRef] [PubMed]

162. Schüth, F. A vibrant science lives from within. Angew. Chem. Int. Ed. 2016, 55, 14878-14879. [CrossRef] [PubMed]

163. Hickman-Lewis, K.; Cavalazzi, B.; Foucher, F.; Westall, F. Most ancient evidence for life in the Barberton greenstone belt: Microbial mats and biofabrics of the 3.47 Ga Middle Marker horizon. Precambrian Res. 2018, 312, 45-67. [CrossRef]

164. Hayatsu, R.; Anders, E. Organic compounds in meteorites and their origins. Top. Curr. Chem. 1981, 99, 1-37. [CrossRef]

165. Heinz, V.B.; Ried, W.; Dose, K. Thermische Erzeugung von Pteridinen und Flavinen aus Aminosauregemischen. Angew. Chem. 1979, 91, 510-511. [CrossRef]

166. Maden, B.E.H. Tetrahydrofolate and tetrahydromethanopterin compared: Functionally distinct carriers in C1 metabolism. Biochem. J. 2000, 350, 609-629. [CrossRef] [PubMed] 